\title{
ASIAN-AFRICAN LEGAL CONSULTATIVE COMMITTEE: ANNUAL SURVEY OF ACTIVITIES 1995-1996, including the work of its Thirty-fifth Session, held in Manila, 4-8 March 1996*
}

M.C.W. Pinto**

Paragraphs

1. Membership and organization $\quad 1-5$

2. Questions under consideration by the International Law Commission 6-7

3. Legal problems referred to the Committee by participating States 8-13

3.1 The status and treatment of refugees $\quad 8-9$

$\begin{array}{ll}3.2 \text { Law of the sea } & 10-11\end{array}$

$\begin{array}{ll}3.3 & \text { Legal protection of migrant workers } \\ & 12-13\end{array}$

4. Matters of common concern having legal implications 14-22

4.1 United Nations Conference on Environment and Development

4.2 United Nations Decade of International Law
4.4 Mutual co-operation in judicial assistance 21-22

5. Trade law matters 23-26

$5.1 \quad$ World Trade Organization 23

5.2 Legislative activities of the United Nations and other organizations, and regional arbitration institutions

\footnotetext{
"Source: Report of the Thirty-fifth Session ('Report') and related documents prepared by the Secretariat of the AALCC.

*" General Editor

Asian Yearbook of International Law, Volume 6 (Ko Swan Sik et al., eds.

- Kluwer Law International; printed in the Netherlands), pp. 287-327
} 


\section{MEMBERSHIP AND ORGANIZATION}

1. There were forty-three Members of the Committee on 4 March 1996: Bahrain, Bangladesh, China, Cyprus, Egypt, Gambia, Ghana, India, Indonesia, Iran, Iraq, Japan, Jordan, Kenya, Democratic People's Republic of Korea, Republic of Korea, Kuwait, Libya, Malaysia, Mauritius, Mongolia, Myanmar, Nepal, Nigeria, Oman, Pakistan, Palestine, Philippines, Qatar, Saudi Arabia, Senegal, Sierra Leone, Singapore, Somalia, Sri Lanka, Sudan, Syria, Tanzania, Thailand, Turkey, Uganda, United Arab Emirates and Yemen. Botswana is an Associate Member.

2. The Thirty-fifth Session of the Committee was held in Manila from 4-8 March 1996 at the invitation of the Government of the Philippines. H.E. Fidel V. Ramos, President of the Philippines delivered the inaugural address, and the Honorable Teofisto T. Guingona, Secretary, Ministry of Justice of the Philippines, an address of welcome. The Honorable Teofisto T. Guingona was elected President, and H.E. Joshua T. Terer, High Commissioner for Kenya at New Delhi, was elected Vice-President of the Committee.

3. H.E. Raul I. Goco, Solicitor-General of the Philippines, was elected Chairman of the Special Meeting on the Establishment of an International Criminal Court, held from 5-6 March 1996. Mr. Ragaa Ismail El-Araby, Prosecutor-General of Egypt, was elected Vice-President of the Special Meeting. Mr. Jun Yoshida, Assistant Director of the Legal Division of the Ministry of Foreign Affairs of Japan, and Mr. Kwabena Baah-Doudu, Minister-Counsellor of the Ghana High Commission in New Delhi were elected, respectively, Rapporteur and Co-Rapporteur of the Special Meeting.

4. The Secretary-General of the Committee, Mr. Tang Chengyuan, Deputy SecretariesGeneral Mr. Tohru Kumada and Mr. Waflk Zaher Kamil, and Assistant Secretary-General Mr. Asghar Dastmalchi, and other members of the AALCC Secretariat were responsible for the organization of the Session.

5. The Committee decided, at the seventh and final plenary meeting of the Session, to accept the invitation of the Government of the Islamic Republic of Iran to hold the Thirty-sixth Session of the Committee in Tehran in March-April 1997, on dates to be determined in consultation with the Secretary-General.

\section{QUESTIONS UNDER CONSIDERATION BY THE INTERNATIONAL LAW COMMISSION}

6. The Committee had before it document AALCC/XXXV/MANILA/96/1 prepared by the Secretariat entitled Report of the International Law Commission on the Work of its Forty-seventh Session, containing a summary of, and comment upon, the Commission's work on the following topics: State responsibility, Draft Code of crimes against the peace and security of mankind, Law and practice relating to reservations to treaties, International liability for injurious consequences arising out of acts not prohibited by international law, and State succession and its impact on the nationality of natural and legal persons. The Committee heard an introductory statement by the representative of the International Law Commission, Dr. Kamil ldris, Deputy Director-General of the WIPO (Report, pp.8-18). 
7. In the resolution (Report, p.81) adopted after discussion of the item (Report, pp.61-64), the Committee inter alia requests that its Secretary-General convey to the Commission (1) its earnest expectation that the formulation of draft articles on the "Code of Crimes against the Peace and Security of Mankind", as well as the first reading of draft articles on "State Responsibility" would be completed at the Commission's session in 1996; (2) its appreciation for commencing work on the topics "Law and Practice relating to Reservations to Treaties" and "State Succession and its Impact on the Nationality of Natural and Legal Persons"; and (3) its interest that the Commission include in its agenda the topic "Diplomatic Protection", and initiate a feasibility study on a topic concerning the law of environment, as suggested by the Commission at its Forty-seventh Session.

\section{LEGAL PROBLEMS REFERRED TO THE COMMITTEE BY PARTICIPATING STATES}

\subsection{The status and treatment of refugees}

8. The Committee had before it document AALCC/XXXV/MANILA/96/2 prepared by the Secretariat, dealing with (a) Model legislation on the status and treatment of refugees (for which see 5 AsYIL 324-44) and comment thereon by some Member States and the UN High Commissioner for Refugees; (b) Establishment of safety zones for displaced persons in their country of origin (for the proposed legal framework currently before the Committee, see 5 AsYIL 344-9); and (c) Deportation of Palestinians in violation of international law, particularly the Fourth Geneva Convention of 1949, and the massive immigration and settlement of Jews in the Occupied Territories.

9. In the resolution (Report, pp.81-2) adopted after discussion of the item (Report, pages 73-8), the Committee

1. Takes note of the proposals advanced by the Representative of the United Nations High Commissioner for Refugees, in particular that of rendering financial and technical assistance to the Secretariat for the purposes of organizing a seminar;

2. Appeals to Member States to take all possible measures to eradicate the causes and conditions which force people to leave their countries and cause them to suffer unbounded misery;

3. Urges Member States who have not already done so to ratify and/or accede to the Convention relating to the Status of Refugees, 1951 and the 1967 Protocol thereto;

4. Requests the Member Governments to transmit their observations and comments on the Model Legislation prepared by the Secretariat and set out in Part A of doc.No. AALCC/ XXXV/Manila/96/2;

5. Also requests the Member Governments to send their comments and observations on the proposed legal framework for the establishment of safety zones for displaced persons in their country of origin prepared by the Secretariat;

6. Directs the Secretariat to study further the concept of safety zone in the light of the comments received and to continue to monitor and assess the developments relating to the establishment of safety zones for the internally displaced persons in their country of origin;

7. Requests the Secretariat to organize in collaboration with and financial and technical assistance of the UNHCR, a seminar in 1996, on the status and treatment of 
refugees to commemorate the 30th Anniversary of the Principles of Refugees adopted by the AALCC at its 8th Session in Bangkok in 1966;

8. Takes cognizance of the hardships suffered by the Palestinian people;

9. Expresses the hope that the next round of the peace process will witness the resolution of outstanding issues including the question of the Jewish Settlements in Palestine and the deportation of Palestinians; ..."

\subsection{Law of the sea}

10. The Committee had before it document AALCC/XXXV/MANILA/ $96 / 3$ entitled Law of the Sea: Report of the Secretary-General containing a summary of developments since the adoption on 28 July 1994 of the Agreement Relating to the Implementation of Part XI of the United Nations Convention on the Law of the Sea, its provisional entry into force on 16 November 1994, and the termination on 28 July 1995 of the period during which it had been open for signature, including an outline of the work of the third and final part of the First Session of the Assembly of the International Sea-bed Authority held at Kingston, 27 February- 17 March 1995, and of the 1995 United Nations Conference on Straddling Fish Stocks and Highly Migratory Fish Stocks.

11. In the resolution (Report, pp.82-3) adopted after discussion of the item (Report, pp.65-7), the Committee

1. Urges the Member States who have not already done so to consider ratifying the Convention on the Law of the Sea;

2. Expresses its appreciation to the Secretariat for the comprehensive brief;

3. Urges the full and effective participation of the Member States in the International Seabed Authority so as to ensure and safeguard the legitimate interests of the developing countries, and for the development of the principle of the Common Heritage of Mankind;

4. Reminds Member States to give timely consideration to the need for adopting a common policy and strategy for the interim period before the commercial exploitation of the deep seabed mineral's becomes feasible, and for this purpose urges Member States to take an evolutionary approach especially to the 'initial function' of the Authority so as to make the International Seabed Authority useful t) the international community and developing countries during this initial period;

5. Urges Member States to co-operate in regional initiative for the securing of practical benefits of the new ocean regime.

\subsection{Legal protection of migrant workers}

12. The Committee had before it a preliminary study of the item prepared by the Secretariat containing an outline of some of the basic issues concerning migrant workers in Asia and Africa, as well as references to the relevant legal framework provided for within the UN system.

13. After discussion of the item (Report, p. 78), the Committee adopted an essentially procedural resolution (Report, p. 86). 


\section{MATTERS OF COMMON CONCERN HAVING LEGAL IMPLICATIONS}

\subsection{United Nations Conference on Environment and Development: follow-up}

14. The Committee had before it document AALCC/XXXV/MANILA/96/4 prepared by the Secretariat, containing an overview of recent developments concerning (a) the 1992 Framework Convention on Climate Change (FCCC or UNFCC) since the first session of the Conference of Parties in March-April 1994 adopted the 'Berlin Mandate' intended to launch a process to strengthen the commitments of Annex I Parties under article 4, paragraphs (a) and (b) of the Convention through adoption of a protocol or other legal instrument; (b) the 1992 Convention on Biological Diversity since the second session of the Conference of Parties held in Jakarta in November 1995; and (c) the 1994 Convention to Combat Desertification (not yet in force), in particular, discussions in the Inter-governmental Negotiating Committee on organizational and substantive measures in anticipation of its February 1996 meeting. The document highlights aspects of the divergence of views between the developed and the developing countries, and contains an outline of AALCC's work-programme on this item. It reads, inter alia:

\section{Introduction}

1. The item entitled "United Nations Conference on Environment and Development: Follow-up" has been briefly considered by the Committee at its 32nd (Kampala, 1993), 33rd (Tokyo, 1994) and 34th (Doha, 1995) Sessions. The Secretariat studies prepared for these sessions focused on the developments in regard to the implementation of Agenda 21 in general, and the three International Conventions namely, the Framework Convention on Climate Change (FCCC), the Bio-diversity Convention and the Convention to Combat Desertification, in particular.

2. The FCCC came into force on 21 March 1994. The first Session of the Conference of Parties (COP) was held in Berlin from 28 March to 7 April 1994. The most important decision adopted at that Conference was the 'Berlin Mandate' which provided for launching a process to strengthen the commitments of Annex I Parties in Article 4 para 2 (a) and (b) of the Convention through adoption of a protocol or another legal instrument. A note reviewing the recent developments in this regard has been set out in Section II of the brief.

3. The Convention on Bio-diversity came into force on 29 December 1993. Section III contains a review of the Second Session of the COP held in Jakarta in November 1995.

4. The Convention to Combat Desertification which was adopted on 17 June 1994, has not yet come into force. As of 1st December 1995 it has been signed by 115 States but so far only 16 States have ratified the Convention. Among the AALCC Member States only Egypt and Senegal are parties to the Convention. The discussions in the Inter-governmental Negotiation Committee have been continuing on organizational and substantive matters. The Eighth Session of the INC-D will be held in Geneva from 5 to 16 February 1996. A note on the outcome of that Session will be prepared by the Secretariat.

\section{UNFCC : AN OVERVIEW OF THE RECENT DEVELOPMENTS}




\section{AALCC Secretariat's Comments.}

1. The guiding principle set out in Article 3(1) of the Convention clearly states that the State parties to the Convention should "protect the Climate System for the benefit of present and future generations of humankind on the basis of equity and in accordance with their common but differentiated responsibilities and respective capabilities. Accordingly, the developed country parties are expected to take the lead in combating climate change and the adverse effects thereof". Implementation of the Convention's provisions by all the Parties is the key aspect.

2. The COP in Berlin recognized that commitments as envisaged in Article 4.2 (a) and (b) were inadequate to achieve the objectives of the Convention. It took the momentous decision to launch a process and gave a time bound mandate to take appropriate action for the period beyond 2000 , including the strengthening of those commitments of Annex I Parties through adoption of a protocol or another legal instrument. However, the priority should be given to implementation of the Convention in accordance with its provisions.

3. Given the complex nature of the issues involved, one can understand why little progress has been made at the two sessions of the AGBM so far. It is, however, imperative that if the task has to be completed in time, the negotiating process needs focused discussion on priority issues.

4. The need to utilize the wealth of information available from the first communications from the Annex I parties and the ongoing work in several International Organizations and National Institutions can hardly be over-emphasized. The IPCC's second Assessment Report finalized recently may set at rest many of the issues which are being raised in the context of analysis and assessment. The emphasis ought to be on the identification of possible policies and measures which might facilitate early elaboration of a legal instrument to supplement the Convention regime.

5. The SBSTA and SBI have an important role to play in the AGBM process. A consensus, if achieved on accelerating the establishment of the Technical Advisory Panels, would further strengthen the institutional mechanism to deal with the matters concerning scientific, technical and technological assessments.

6. Provision concerning mobilization of adequate international resources and transfer of environmentally sound technologies are the two key issues which reflect the concern and interest of the developing countries in their effective participation in the implementation of the Convention. These issues need to be addressed seriously in the AGBM process.

7. While no consensus has yet been achieved, it appears that the proposed legal instrument could be in the form of a protocol together with certain annexes. Such an instrument therefore should contain in clear and precise terms the commitments of Annex I Parties indicating quantified targets and specified time-frames.

8. The very purpose of the AGBM is to find ways to strengthen the commitments of Annex I parties. Paragraph 2.b of the Berlin Mandate clearly states that "the process will not include any new commitments for parties not included in Annex 1, but reaffirm" existing commitments mentioned in Article 4.1 and continue to advance the implementation of 'these commitments. Some of the developing countries are obliged to submit their national communications in 1997 but that is contingent upon 
providing them necessary financial and technological assistance whether by the GEF or from other sources.

9. The Second Meeting of the Conference of the Parties to the FCCC scheduled in Geneva from 8 to 19 July 1996 will be an occasion to review the progress thus far made by the AGBM process. It is hoped that by that time issues concerning rules of procedure and composition of the Bureau will he resolved and the AGBM would be able to register satisfactory progress on substantive issues, particularly on the preparation of a working draft on the proposed legal instrument for adoption in 1997.

III. THE CONVENTION ON BIOLOGICAL DIVERSITY: PROGRESS OF IMPLEMENTATION AT NATIONAL AND INTERNATIONAL LEVELS

\section{AALCC'S FUTURE WORK-PROGRAMME IN THE FIELD OF ENVIRON- MENT}

1. Issues concerning environmental protection have been on the agenda of the AALCC for over 20 years. After preliminary discussions at the Tehran (1975) and Kuala Lumpur (1976) Sessions, a detailed questionnaire was sent to the Member Governments with a view to seek information on their national legislation and the administrative machinery including implementation measures. The information thus collected was examined by an Expert Group which met in 1978. The Expert Group recognized the importance of collective regional action to tackle marine pollution problems. It also suggested that the Secretariat should take up the question of promoting ratification of important international conventions in the field of protection of the marine environment.

2. A second meeting of the Expert Group which was held in 1979, identified areas for priority consideration. A third meeting of the Expert Group which was held in 1982 in co-operation with IMO and UNEP considered the ways and means to promote ratification of the conventions dealing with the prevention and control of marine pollution. Another meeting was held in Jakarta in 1984 to consider the revision of the IMO Convention on Civil Liability and the Fund Convention. In 1989, the AALCC took up the issues concerning a ban on transboundary movement of hazardous wastes.

3. The next phase of the AALCC's initiatives began in 1990 against the backdrop of the United Nations decision to convene the Rio Conference on Environment and Development in 1992. The AALCC Secretariat was actively involved in the preparatory phase and prepared extensive material to assist the Member Governments. As a follow-up to the UNCED, the AALCC Secretariat has been engaged in monitoring the developments in the context of the implementation of Agenda 21 and the three recent environmental conventions namely, the Framework Convention on Climate Change, the Bio-diversity Convention and the United Nations Convention to Combat Desertification.

4. It would be seen from the foregoing account that the AALCC has kept pace with the developments in the field of environment and took up issues of topical importance. It would, therefore, be desirable to give impetus to AALCC's work and 
identify areas where it could provide useful and productive service to its Member Governments.

5. Broadly, some of the areas which the Member Governments may wish to consider for the future work-programme of the AALCC Secretariat could be as follows:

(i) Preparation of studies on important international environmental conventions with a view to promoting their wider adherence by the AALCC Member States;

(ii) Establishment of co-operative programmes with the United Nations Agencies and other Inter-governmental Organizations and research institutions engaged in activities related to environmental matters. In that context, co-operation with UNEP could be most useful in matters concerning capacity building;

(iii) Organization of training programmes for the officials of the Member Governments to promote awareness and skills to deal with legal problems in the field of environment; and

(iv) Constitution of a panel of legal experts from the AALCC Member States whose services could be utilized by the Member Governments.

6. The implementation of such a vast programme would be possible only when there is financial and material support from the Member Governments. It may be recalled that the Committee has already established a Special Environment Fund in 1991. The Governments of Saudi Arabia and Myanmar contributed US\$ 25,000 and US\$ 500 respectively to this Fund. This was utilized to meet the expenses of participation of the Secretariat officials in the environmental meetings during 1992 and 1993. The Fund now needs replenishment. The Committee, at its Doha Session urged the Member Governments to consider making voluntary contributions to the Special Fund on Environment. This would help immediately to launch new initiatives related to the AALCC's work programme on Environmental Law, particularly the convening of a meeting jointly with the UNEP.

15. After discussion of the item (Report, pp. 67-70) the Committee adopted an essentially procedural resolution (Report, p. 83).

\subsection{United Nations Decade of International Law}

16. The Committee had before it two documents prepared by the Secretariat: document AALCC/XXXV/MANILA/ $96 / 5$, containing a Note on the item by the Secretary-General covering inter alia the AALCC seminar on the role of the International Court of Justice, the 1995 Meeting of the Legal Advisers of Member States of AALCC held at United Nations Headquarters, and activities to mark the 40th anniversary of the Bandung Conference and of AALCC, and the 50th anniversary of the United Nations, as well as the anticipated end (1999) of the UN Decade of International Law; and document AALCC/XXXV/MANILA/ 96/10 entitled AALCC Legal Advisers' Meeting: Report of the Secretary-General.

17. After discussion of the item (Report, pp. 64-5), the Committee adopted an essentially procedural resolution (Report, p. 84).

\subsection{Proposed establishment of an International Criminal Court}

18. The Committee had before it document AALCC/XXXV/MANILA/96/6 entitled International Criminal Court: a background note, containing inter alia an overview of 
the Draft Statute for an International Criminal Court, and a summary of the Report of the United Nations ad hoc Committee on the Establishment of an International Criminal Court dealing with contentious issues under discussion, as well as the views and comments of the AALCC Secretariat. The Committee also had before it the report of AALCC's Special Meeting on the subject held during the Manila Session (Report, pp. 25-29). The Report of the Special Meeting contains the following:

12. The following countries presented their respective positions during the Special Meeting: Islamic Republic of Iran, Singapore, Japan, Ghana, Egypt, People's Republic of China, Sudan, Republic of Korea, Tanzania, India, Cyprus, Thailand, Qatar, Pakistan, Sri Lanka and the Philippines. Australia and Finland submitted their views as observers. Some countries made only oral presentations. The following trends were identified in the country positions presented by the various delegations :

\section{A. MODE OF ESTABLISHMENT}

13. The delegations unanimously favoured the establishment of an independent and impartial international criminal court, free from political pressures and tendencies. However, they differed on the mode of establishment of the same, viz, whether it should be through a resolution of the UN General Assembly, a treaty or by an amendment of the UN Charter. The majority favoured the establishment of the Court through a treaty or by a multilateral agreement. While accepting the difficulties involved in amending the UN Charter, some delegations also noted the difficulties of getting a sufficient number of accessions to the treaty proposal.

Few delegations were not inclined to keep the ICC independent from the UN to allow it to function as a completely independent judicial body. Many of the delegations generally sought the universality of the Court so as to ensure its effectiveness.

\section{B. THE PRINCIPLE OF COMPLEMENTARITY}

14. Several delegations sought a clear definition of the principle of complementarity. The mere reference to the principle in the preambular paragraphs, according to many delegations, did not adequately ensure its clarity. Emphasis was made by some delegations on the drawing up of clear jurisdictional boundaries between the national courts and the ICC to avoid unnecessary overlapping in the administration of justice over international crimes. Therefore, delegations sought to stipulate in the main text the principle of complementarity.

15. The principle of complementarity is derived from the sovereignty of States. The clear expression of this principle, according to one delegation, meant working, as far as possible, within the confines of existing criminal procedures and existing regimes governing extradition and mutual criminal assistance. The said delegation further noted that the achievement of balance in the principle would command the widespread acceptance of States which was essential to the draft Statute's effectiveness. References were made to Article 42 of the ILC draft which permitted the Court to consider whether proceedings in national courts "were not impartial or independent or were designed to shield the accused from international criminal prosecution or the case was not diligently prosecuted". This Article was understood by some delegations as an infringement of the sovereignty of States, and thus was not acceptable. 
16. Majority of the delegations favoured a consensual approach towards the application of the principle of complementarity. According to one delegation, this principle was crucial and only under exceptional circumstances, where no appropriate alternative might be found, would an ICC be called upon to fill in the gap.

\section{ISSUES PERTAINING TO JURISDICTION AND APPLICABLE LAW}

17. The precision in the definition of the ICC's jurisdiction was felt extremely essential for the effective operation of the Court as well as upholding the principle nullum crimen sine lege. Several delegations required a clear definition of the jurisdiction of the ICC in the Statute. The role of the Statute, it was pointed out, should be to set out the judicial mechanism for the prosecution of crimes rather than to deal with the substantive definitions of the crimes themselves. It was also suggested that the definitions of crimes under the purview of the Court could properly be made in the Statute or be dealt with by the respective multilateral treaties creating or embodying those crimes. Majority agreed that the jurisdiction of the Court could be limited to the most serious crimes of international concern, notably, genocide, serious violations of the laws and customs applicable to armed conflicts and crimes against humanity. However, there was no agreement on the precise definition of 'aggression' and its determination. Therefore, its inclusion was not unanimously accepted. Several delegations, however, felt that crimes of drug trafficking, terrorism and piracy could be under the scope of the Court.

18. One delegation held the view that Article 20 should be amended by deleting references to the crime of aggression and crimes against humanity. It also sought in Article 20(c) specific provisions referring to the 1949 Geneva Conventions defining the serious violations of the laws applicable to armed conflicts. With respect to aggression and crimes against humanity, it was pointed out by some delegations, that these could only be dealt with upon the finalization of the draft Code of Crimes against the Peace and Security of Mankind. However, one delegation expressed the opinion that the Court should exercise jurisdiction in respect of the 'hard core' crimes until the draft Code of Crimes against the Peace and Security of Mankind was completed. It was also pointed out that the concept of 'grave breaches' instead of 'serious violations' should be brought in while dealing with the crimes connected with laws and customs of war.

19. Considering the evolution of the PCIJ and its successor ICJ, one delegate noted that only when the system of law had matured to an advanced degree after centuries, that such institutional mechanisms were set up to settle all disputes under international law. So, in his view, it was doubtful whether international criminal law had developed to the same degree to warrant a permanent Court of General, International, Criminal Jurisdiction. Furthermore, he also noted the difficulties involved in determining the offences/crimes that would come within the jurisdiction of the Court and their relations with the draft Code of Crimes against Peace and Security of Mankind. For instance, he pointed out, it was not clear as to whether the crime of aggression would cover political or economic aggression or what violations of the laws of war would be 'serious' and what would not be. He agreed with the assertion that individuals should have the responsibility for certain serious crimes at the international level when they enjoyed certain rights at that level. However, in his view that did not necessarily call for the mechanism of a permanent Court of General, International, Criminal Jurisdiction. So, he felt that the proposed Court could be convened as and when required, like all its predecessors. 


\section{ICC AND ITS RELATIONSHIP WITH THE SECURITY COUNCIL}

20. Several delegations pointed out that the inherent jurisdiction envisaged for the ICC upon referral by the Security Council (Article 23 of the Draft Statute) could cloud the objectivity and independence of the ICC and hence, not in the interest of developing a uniform, non-discriminatory, and impartial international criminal justice system. One delegation was of the view that in the case of the crime of genocide, the invocation of the jurisdiction of the ICC should be only on the basis of consent of all concerned States and not as proposed under Article 25 of the draft Statute; otherwise it might amount to a backdoor amendment to an existing treaty. It was the view of another delegation that the logic behind the principle of separation of powers between judicial and executive branches, as employed in domestic legal systems, had to be taken into account in the context of the relationship between the Security Council and the ICC.

21. Some delegations would want to give the Security Council only a limited role vis-à-vis the ICC. According to one delegation, although the ICC should be independent from the influence of the Security Council, it should maintain adequate respect for the decisions and resolutions of the Security Council. This was felt necessary in the interest of preserving international peace and security which was the primary responsibility of the Security Council. One delegation, referring to Article 2 which incorporates the relationship between the ICC and the UN, sought clarification on the scope of Article 2, particularly concerning the role which the Security Council was envisaged to play in the proceedings before the Court.

\section{E. PROCEDURAL ISSUES}

22. Some delegations favoured the rules of the Court in relation to, inter alia, the conduct of investigations, procedure and the rules of evidence to be drafted together with the Statute. According to them, procedural issues were fundamental to ensuring the fairness of the Court's proceedings and the adequacy of the protection accorded to the rights of the accused. Several delegations pointed out that the role of a prosecutor and surrender of the accused by States, and waiving of national jurisdiction were crucial issues and therefore, needed to be settled on the basis of broad consensus. Some delegations also sought that extensive pre-trial investigations be left to the courts of the complainant State.

23. One delegation sought to have more clarity with regard to the relationship between investigation, arrest and pre-trial detention by the Court and by a State party rendering judicial assistance. Some delegations found paragraph 2 of Article 45 inappropriate as it allowed decision to convict an accused of a criminal charge to be reached by a mere majority of three out of the five judges of the trial chamber. Reference was also made to the fact that the draft Statute did not require all the judges to be present continuously throughout the hearings. Some delegations sought to know what factors should be taken into account to decide the 'gravity of the crime' and the 'individual circumstances of the convicted person', such as (a) the aggravating as well as mitigating factors; (b) the extent and severity of the damage or injury caused by the commission of the offence; and (c) the antecedents of the convicted persons. References were made by some delegations to the necessity of providing adequate and proper protection to victims and witnesses.

\section{F. CONSENT AND ACCOUNTABILITY}

24. Several delegations favoured the exercise of jurisdiction by the ICC through consensus i.e. jurisdiction to be conditional upon the acceptance by concerned States 
in a given case. It was also pointed out that while the consent of the custodial and territorial State was considered generally necessary, the consent of the State of nationality of the accused and the State of the victim were also emphasized as important. Some delegations, therefore, sought to invoke the Court's jurisdiction only by making an express declaration to this effect i.e. by 'opting-in' procedures. However, many delegations felt that the rigid consensual basis of jurisdiction implied in the 'opting-in' system should not frustrate the objective of the Court.

25. One delegation referring to the principle of accountability pointed out that both the ICC and sovereign States had to be held accountable for actions taken or refusals to act. The delegation also referred to the various grounds on which the ICC could be held accountable. These were respect of human rights of the accused, judicial nature of the decision and the equal justice for all. On the other hand, it was pointed out that when a State refused to co-operate with the ICC, either in the case of transfer of the accused from national jurisdiction to ICC or arresting an accused who happened to be in its territory, that State should provide ICC and the international community through the ICC the reasons for such a refusal.

26. The Chairman invited H.E. Mr. Chusei Yamada, Member, International Law Commission, to address the Special Meeting. In his statement H.E. Mr. Yamada referred particularly to the close co-ordination between the draft Code of Crimes against the Peace and Security of Mankind and the draft Statute of the ICC. Dr. P.S. Rao, Chairman, International Law Commission, noted the problems which might come in the way of effective functioning of the ICC. He said that various quasi-legal and political factors hindered the effective functioning of the ICC. He wondered whether State parties were in a position to accept international criminal jurisdiction vis-à-vis national jurisdiction. Welcoming the establishment of the Court, he made pertinent reference to the contentious issues and suggested that these aspects should be considered with utmost care. In view of this, he felt that the establishment of the Court should not be rushed through. Dr. Idris Kamil, Member, International Law Commission, in his address, appraised the Special Meeting of the work completed on the Draft Code of Crimes by the ILC until its last session.

27. According to one delegation, Article 6 of the draft Statute, providing for the appointment of judges, did not adequately reflect the necessary qualifications and experience required. Two experts, Mr. Adriaan Bos and Prof. Hafner while responding to the discussion requested all the countries to take part in the forthcoming Preparatory Committee Meeting to be held on March 25-April 12, 1996 in New York. ...

19. The Committee heard statements by Mr. Adriaan Bos (Netherlands), the Chairman of the UN ad hoc Committee, and by Professor Gerhard Hafner (Austria), the Chairman of the Working Group of the UN ad hoc Committee.

20. After discussion of the item (Report, pp. 79-80), the Committee adopted an essentially procedural resolution (Report, p. 84). 


\subsection{Mutual co-operation in judicial assistance}

21. The Committee had before it document AALCC/XXXV/MANILA/96/7 prepared by the Secretariat, entitled Extradition of Fugitive Offenders, containing, inter alia, draft articles on the subject for inclusion in a treaty, as well as a note and commentary thereon prepared by the Secretariat of AALCC:

\section{EXTRADITION OF FUGITIVE OFFENDERS}

1. The promotion of mutual judicial co-operation among the Asian-African countries remains one of the primary concerns of the AALCC. In furtherance of this objective, the AALCC at its Arusha Session (1986), while considering the draft of the mutual bilateral arrangements for judicial co-operation in criminal matters in regard to service of process, recording of evidence and other related matters, expressed the view that as a further step forward in promoting mutual judicial co-operation, the current problems and issues concerning extradition of fugitive offenders should be taken up for study.

2. It should, however, be noted that the topic 'Extradition of Fugitive Offenders' was on the agenda of the Committee since its establishment in 1956. In 1956 itself, it may be recalled, the Government of the Union of Burma by a reference made under Article 3(b) of the Committee's Statutes, had requested consideration of this topic. India, by a separate reference, had requested the opinion of the Committee on certain specific issues. Japan had submitted a memorandum dealing with various issues raised in the two references. The Committee considered these various viewpoints till 1961 (in four sessions) and presented a final report in February 1961. That report contained a set of articles on the principles concerning extradition of' fugitive offenders together with commentaries, without expressing any opinion whether extradition should take place under a multilateral convention or a bilateral treaty.

3. The need for the consideration of this topic since the Arusha Session (1986) arose as a result of certain new developments. Although the general pattern of extradition arrangements on a bilateral basis continues to be the practice, some multilateral arrangements as between neighbouring and closely-knit countries are evolving. For instance, some special arrangements between the countries of the Commonwealth have been contemplated, on the lines of the pattern which had previously existed for extradition of offenders within the British Empire under the Fugitive Offenders Act of 1881. The extradition arrangements at the multilateral level could be identified in the following classes of offences, namely, terrorism, unlawful seizure of aircraft. acts against safety of civil aviation, crimes against internationally protected persons and taking of hostages.

4. Considering some of the above mentioned developments, particularly in the multilateral fora, the AALCC Secretariat submitted a preliminary study to the Bangkok Session (1987). That study analyzed the AALCC's 1961 principles in the light of new developments. It also undertook the examination of each article in the 1961 principles with the particular emphasis on the following issues, namely, the scope of extraditable crimes, political offences exception, the requirement of prima facie evidence, the principle of double jeopardy and the rule of speciality. The Singapore Session (1988), while considering that study, suggested that it would he worthwhile to study the developments within the Commonwealth, especially the 1966 Com- 
monwealth Scheme Relating to the Rendition of Fugitive Offenders as revised in 1983 and 1986.

5. Pursuant to the above suggestion, the AALCC Secretariat prepared a study for the Nairobi Session (1989), entitled, "Extradition of Fugitive Offenders: A Brief Comment on the Commonwealth Scheme for the Rendition of Fugitive Offenders as Reviewed in 1983 and 1986". While considering this study, the Nairobi Session noted that the developments within the Commonwealth would be a useful source for the Committee's efforts to update its principles. The Nairobi Session also directed the AALCC Secretariat to prepare new draft principles on extradition as a basis for Committee's future deliberations. Accordingly, the AALCC Secretariat prepared a set of draft articles on extradition for the 29th Session held at Beijing (1990). While taking note of the draft articles, the Committee declared that it was necessary to discuss the report submitted in-depth beforehand. It also felt that it would be desirable to hold an intersessional meeting of experts on this topic. Due to lack of time at that Session, thorough discussion on the draft articles could not be undertaken.

6. The AALCC Secretariat put forward the draft articles, with a brief note on the recent developments, before the Cairo Session (1991).* Once again, due to paucity of time the Cairo Session did not take up this item for discussion. In subsequent sessions, i.e., 1992 onwards, this item did not get consideration on account of the Committee's extensive work programme on the United Nations Conference on Environment and Development (UNCED) and other matters.

7. In recent times, however, the issues relating to extradition have assumed importance on account of UN's increasing emphasis on 'crime prevention' and the evolution of 'criminal justice' programmes. For example, the Ninth United Nations Congress on the Prevention of Crime and the Treatment of Offenders held in Cairo from 29 April - 8 May 1995 (Ninth UN Crime Congress, hereinafter), inter alia had on its agenda the following topic which elaborately dealt with the question of extradition: "International Cooperation and Practical Technical Assistance for Strengthening the Rule of Law : Promoting the United Nations Crime Prevention and Criminal Justice Programme". One of the recommendations of the Ninth UN Crime Congress noted the UN's role in enhancing multilateral co-operation aimed at combating crime and to provide technical assistance to developing countries. This Congress also urged the UN Member States to intensify efforts to strengthen the rule of law and to promote the use and application of UN standards and norms in crime prevention and criminal justice giving due consideration to the political, economic, social and cultural conditions. To achieve this objective, the Ninth UN Crime Congress found it necessary to intensify sub-regional and regional co-operation in crime prevention and criminal justice, within the framework of regional arrangements, infrastructure and mechanisms.

8. Considering the escalation of organized crime, particularly in the cases of transnational crimes, mutual assistance and co-operation is now increasingly necessary. In other words, the transnational forms of criminality, such as drug trafficking, terrorism and hijacking necessitate bilateral and multilateral co-operation among States. For instance, it may be necessary to acquire the necessary evidence for prosecution; or it may be necessary to deal with the convicted offender to investigate the crime. In these cases, extradition of the offenders would help in meeting the objectives of criminal justice.

* See 1 AsYIL 230 et seq. 
9. The AALCC Secretariat, while preparing the revised draft articles on extradition, has made an attempt to take into consideration various aspects of the law of extradition as evolved by both Common Law and Civil Law systems. Furthermore, the membership of the AALCC comprises States from different legal systems, in particular the criminal justice systems. In order to reflect the principles of criminal justice systems as evolved in the legal systems of the Asian and African States references have been made to some multilateral, regional, bilateral and municipal extradition arrangements. These are: the European Convention on Extradition 1967; 1986 Commonwealth Scheme Relating to the Rendition of Fugitive Offenders; and the Inter-American Extradition Convention, 1981. The UN study of 1985, entitled "Extradition for Drug-Related Offences: A Study of Existing Extradition Practices and Suggested Guidelines for Use in Concluding Extradition Treaties" provides a useful insight into the practices relating to the law of extradition.

10. The Draft Articles on Extradition of Fugitive Offenders have been annexed to this note. These articles, after due consideration by the Committee, could be formulated as a model framework.

\section{ANNEX}

\section{DRAFT ARTICLES ON EXTRADITION OF FUGITIVE OFFENDERS}

\section{Article 1 : Obligation}

The Contracting Parties undertake to surrender to each other under the present Treaty/Convention, persons who are within the jurisdiction of one party and are being prosecuted or have been convicted by the judicial authorities of other parties.

\section{Commentary}

Although there appears to be a fair measure of agreement among states on the general principles relating to the extradition of fugitive offenders, the position regarding a State's obligation to extradite a fugitive and the legal basis for the same continues to be debated. There is a general agreement that in juridical terms "no legal duty is imposed by customary international law on States to extradite fugitive offenders". ${ }^{1}$ However, states, perhaps due to the exigencies of circumstances also hold that "extradition may, in the absence of a treaty, be effected by way of international co-operation in suppression of crimes on a reciprocal basis". ${ }^{2}$ In view of the existing controversy between theoretical positions such a non-obligation to extradite in the absence of a treaty and practical considerations that without extradition international crimes could not be controlled, every arrangement on extradition generally provides this enabling clause. Therefore, the AALCC framework should also provide for this.

\section{Article 2 : Extraditable Offences}

(1) Extradition shall not be granted unless the act constituting the offence for which the person sought is being prosecuted or has been convicted is punishable at least by two years of imprisonment under the laws of both the requested and requesting States.

(2) Where the extradition of a person is sought for the execution of a sentence involving deprivation of liberty, the duration of the sentence still to be served shall be at least six months.

(3) The principle of retroactivity of crimes shall not be applicable for the purposes of extradition. 


\section{Commentary}

One of the major questions arising in respect of extradition is the method of qualifying an extraditable offence. There are at least two differing methods namely, the enumeration ('list') method and eliminative ('no list') method. The adoption of either of these two methods has always been the prerogative of the parties concerned whether it is in the context of bilateral or multilateral extradition arrangements.

The enumerative method which specifies each offence for which extradition may be granted is based on an exhaustive list of extraditable offences, either in the text of an agreement, or in an appendix forming an integral part of the treaty. Historically speaking this is the older approach, which was used in most extradition arrangements in the nineteenth and early twentieth centuries ${ }^{3}$ irrespective of the legal system involved. Many of the municipal legislations ${ }^{4}$ as well as bilateral treaties ${ }^{5}$ even today adopt the enumerative method.

The enumerative method had, however, in the course of its existence, revealed a number of problems in terms of both elaboration and application of exhaustive lists. ${ }^{6}$ One of the visible shortcomings of this method relates to the choice of offences and their exact definition in the context of different legal systems. ${ }^{7}$ The most important drawback of this enumerative method however, would seem to be the permanent need to update the list of offences vis-à-vis emerging new crimes. ${ }^{8}$ Therefore this method is slowly giving way to the other method, namely, the eliminative method.

The eliminative method is the more recent approach and in general, it is the one usually applied by the civil law countries including the socialist countries. It is also the system incorporated in several international conventions on extradition. The eliminative method defines extraditable offences by reference to a maximum or minimum penalty which may be imposed. Some of the multilateral conventions that have adopted the eliminative method are: The Arab League Extradition Convention $1962,{ }^{9}$ the European Convention on Extradition $1957,{ }^{10}$ the Convention de l'organisation de la Communauté Africaine et Malgache 1961, ${ }^{11}$ the Benelux Extradition Convention $1967^{12}$ and the Inter-American Convention on Extradition, $1981 .{ }^{13}$

Even the practice within the Commonwealth is yielding to the eliminative (no list) method. The Commonwealth Revised Scheme Relating to the Rendition of Fugitive Offenders 1986 has opted for eliminative method, ${ }^{14}$ whereas the original scheme adopted in 1966 provided for the enumerative method. A vivid illustration of Commonwealth (common law) countries opting for eliminative (no list) method of late, is the Indo-Canadian Extradition Treaty 1987..$^{15}$

As seen earlier, one of the major shortcomings of the enumerative list method is the constant need to update the list of the extraditable offences vis-à-vis the emergence of new crimes. Of late a few new crimes such as computer frauds, due to their serious consequences, frequency and the difficulty in tracing the offender, have posed serious problems for the international community. The enumerative method, however, would not automatically cover these new crimes for purposes of extradition and the time-consuming process of updating the crimes might enable the offender to escape punishment. Therefore, a new trend is emerging towards their inclusion as an extraditable offence either through specialized multilateral conventions or by unilateral or bilateral arrangements. Such crimes would include fiscal offences, particularly international white collar crimes, drug and narcotics offences, terrorist acts, marine as well as nuclear offences.

Traditionally, fiscal offences were treated as exceptions to extradition. However, recent trends indicate the reversal of such attitude. There is a increasing agreement in various quarters to incorporate fiscal and similar offences as extraditable offences. For instance, the Second Additional Protocol to the European Convention, 1978 , establishes a duty to extradite for "offences in connection with taxes, duties, customs, or exchange regulation of the same kind as of the requesting party". ${ }^{16}$ 
Moreover, while recognizing the different fiscal structures prevailing in various countries, the Convention attempts to prevent any possibility of refusal on the ground of dissimilarity of fiscal regulations between the requesting and the requested states. ${ }^{17}$

The Ad Hoc Inter-Governmental Working Group on the Problem of Corrupt Practices in International Commercial Transactions in 1977, in its report, suggested certain measures relating to extradition for the offences of all forms of illicit payments. $^{18}$

The Council of Europe in $1981^{19}$, having identified as many as sixteen instances as economic offences, recommended that :

"The Governments of the member states intensify their co-operation at international level in particular by signing and ratifying the European Conventions on Mutual Assistance in Criminal Matters and on Extradition, the Protocols thereto and any other international instruments facilitating the prosecution and punishment of economic offences".

International white collar crimes figure as an important item during the 1982 review meeting of the Commonwealth Scheme relating to the Rendition of Fugitive Offenders ${ }^{20}$ This resulted in inclusion of a general clause to the list of 'returnable offences' to the effect that further offences which are returnable under the law of the requested part of the Commonwealth should be treated as returnable "notwithstanding the fact that any such offences are purely of a fiscal character". It may be pointed out here that in view of the 1986 agreement within the Commonwealth that all offences punishable with two years of imprisonment are returnable, most of the fiscal offences would seem to have been covered as extraditable offences.

The set of crimes that led to a wide acceptance among the States and which resulted in many instances in the redoing of their extradition arrangements are crimes that are considered as terrorist acts. Although traditionally, extradition arrangements provide that offfences such as murder, manslaughter, causing grievous harm etc. are extraditable offences, new forms of crimes that are committed in the context of international political and ideological pursuits as tactics needed to be redefined whether they were offences for extradition purposes or extradition itself by virtue of their being committed for political interests.

Several international conventions have come into existence with a view to combating and controlling several such specialized crimes irrespective of the motives for which they are committed. They would include: the Convention on Offences and Certain Other Acts Committed on Board Aircraft, signed at Tokyo on 14 September $1963^{21}$, the Convention for the Suppression of Unlawful Seizure of Aircraft, signed at The Hague on 16 December $1970^{22}$, the Convention for the Suppression of Unlawful Acts against the Safety of Civil Aviation signed at Montreal on 23 September $1971^{23}$, the Convention on the Prevention and Punishment of Crimes Against Internationally Protected Persons, including Diplomatic Agents, signed at New York on 14 December $1973^{24}$, the International Convention Against Taking of Hostages adopted at New York on 13 December 1979 as well as the Convention on the Physical Protection of Nuclear Material, concluded at Vienna on 3 March, 1980.

In addition to the adoption of international conventions on instances of terrorism, the increasing incidence of these acts has also led to the conclusion of some regional conventions for the suppression of terrorism. These include the Convention to Prevent and Punish Acts of Terrorism Taking the Form of Crimes Against Persons and Related Extortions that are of International Significance, 1971 (OAS Convention) ${ }^{25}$, the European Convention on Suppression of Terrorism 1979 26 , the Agreement on the Application of the European Convention for the Suppression of Terrorism, 1979 (Dublin Agreement) ${ }^{27}$ and the SAARC Regional Convention on Suppression of Terrorism, $1987 .{ }^{28}$ 
There are also bilateral extradition arrangements seeking to suppress terrorist activities. For instance, the United States-Cuba Memorandum of Understanding on Hijacking of Aircraft and Vessels and Other Offences, $1973^{29}$, the Afghanistan-USSR Agreement on the Hijacking of Aircraft 1971 and the Indo-Canadian Treaty on Extradition. ${ }^{30}$

Although the practice relating to the inclusion of drug-related offences in extradition treaties started even before the Second World War, the two post-war international instruments ${ }^{31}$ that serve as the basic legal framework for containing the drug offence seem to suffer from inadequacies. For instance, under these conventions, the requested state can refuse extradition if it considers that the offence is not serious enough.

However, in light of the increasing activities in drug trafficking and its serious consequences, the General Assembly has termed the trafficking in narcotic drugs as 'international criminal activity', the eradication of which is the 'collective responsibility of all states'.

Besides this, many extradition arrangements (among common law countries or between them and other countries) apply what is known as 'mixed approach' by adding a general eliminative clause to the list of extraditable offences. A number of more recent treaties apply an even broader kind of 'mixed approach'. They provide a list of extraditable offences, subsequently add an eliminative clause, and then augment that scheme by a further provision to the effect that extradition should be granted also in respect of any other offence that, according to the laws of both contracting parties, is one for which extradition may be granted. Australia, in particular, has used this approach in a number of treaties.

To sum-up, while the departure from the enumerative or list method is clear, the eliminative or no list method is increasingly resorted to qualify the extraditable offences. With the Commonwealth Scheme adopting the eliminative method, it has become almost universal practice.

It may be pointed out that in 1961, a majority of member States of the Committee favoured the eliminative method. Since however there was no unanimity, the Committee in its final report, provided three alternatives.

The somewhat long commentary on this aspect is the consequence of the need to place the evolving trend relating to qualification of extraditable offence in proper perspective. However, it is recommended that the Committee, a unique forum comprising members belonging to the major legal systems of the world should not brook any delay in adopting the eliminative (no list) method.

Clause (2) is to meet the situation wherein a person is sought to be extradited for purposes of serving a sentence which has already passed by the competent authority of the requesting state which the fugitive has evaded.

All the major extradition arrangements including that of the Committee's 1961 principles have provided different terms of imprisonment before and after trial for extradition.

Clause 3 is based on the well established principle that there should not be any post facto laws regarding crimes. A specific mention of this time-honoured principle is herein called for in view of the possibility of a party to an extradition treaty specifying some crimes with retroactive effect in the hasty move to capture some individuals.

\section{Article 3 : Political Offence Exception}

(1) Extradition shall not be granted for political offences. The requested state shall determine whether the offence is political.

(2) The requested state has the right to seek information and clarification from the requesting state as to the nature of the offence for which extradition has been requested in order to determine whether the offence is of a political character or not. 
(3) Notwithstanding the provisions of clauses (1) and (2) the following offences shall not be regarded as political offence or offences of a political character.

(4) (a) an offence within the scope of the Convention for the Suppression of Unlawful Seizure of Aircraft, signed at the Hague on December 16, 1970;

(b) an offence within the scope of the Convention for the Suppression of Unlawful Acts Against the Safety of Civil Aviation, signed at Montreal on September 23, 1971;

(c) an offence within the scope of the Convention on the Prevention and Punishment of Crimes Against Internationally Protected Persons, including Diplomatic Agents, signed at New York on December 14, 1973;

(d) any offence within the scope of recent IMO Conventions (against hijacking of ships);

(e) an offence within the scope of any Convention to which both contracting parties are party and which obligates to prosecute or grant extradition if the requested State is not willing to prosecute;

(f) offences related to terrorism, which are as follows:

(i) murder, manslaughter, assault causing bodily harm, kidnapping, hostage taking and offences involving serious damage to property or disruption of public facilities and offences relating to firearms, weapons, explosive or dangerous substances (when used as a means to perpetrate indiscriminate violence involving death or serious bodily injury or serious damage to property);

(ii) an attempt or conspiracy to commit an offence described in subparagraphs (a) through (( $\mathrm{f}$ ) or counselling the commission of such an offence or participation as an accomplice in the offences so described;

(iii)an offence against the life or person of a Head of State or a member of his immediate family or any related offence (i.e. aiding and abetting, or counselling or procuring the commission of, or being an accessory before or after the fact to, or attempting or conspiring to commit such an offence ;

(iv)an offence against the life or person of a Head of Government, or of a Minister of a Government, or any related offence as aforesaid.

\section{Commentary}

The obligation to extradite an offender under any arrangement has always been subject to some exceptions, such as the political offence exception. ${ }^{32}$ Notwithstanding the fact that there exists no precise definition of political offence, all extradition arrangements refer to political offence exception as a standard clause, and non extradition of political offenders has become a general norm relating to extradition. A raging controversy continues ever since its advent regarding whether an act in question is political or criminal and who will determine - judiciary or executive. Conflicting legislative and judicial precedents still continue to compound the difficulties of this concept and in the course of its development the exception has been given different treatment. It may be mentioned that despite the difficulties surrounding the definition of political offence, certain exceptions to this have received nearly universal acceptance along with the advent of the modern extradition practice. They would include: 'clause d'attentat', international war crimes, genocide, hijacking, hostage taking etc. and a host of other crimes as designated by some of the recent regional and bilateral arrangements on the suppression of terrorism.

Although there is no universally acceptable definition for the mutually exclusive terms of terrorism and political offence, the recent trend is to specify several acts as terrorist acts which are extraditable and do not attract the political offence exception. For instance the SAARC Convention provides the following acts as not political harm: 
"Murder, manslaughter, assault, causing bodily harm, kidnapping, hostage-taking and offences relating to firearms, weapons, explosives and dangerous substances when used as a means to perpetrate indiscriminate violence involving death or serious bodily injury to persons or serious damage to property."33

Thus, all arrangements on extradition, while honouring the political offence exception also categorically provide the circumstances and acts that would not be treated as political offences. In view of this fact the Secretariat wishes to emphasize to the Committee the inadequacy of merely mentioning of the political offence exception by stating "extradition shall not be granted for political offenders" as done by the Committee's 1961 principles. It would therefore be necessary to specifically provide for the increasing number of instances that are now considered as not within the ambit of 'political offences' for the purpose of extradition. That is why the draft article seeks to provide the long list of exceptions to the political offences in the text itself. The Committee may wish to consider this list to establish the validity of each exception and to decide whether it should be considered exhaustive or not.

Moreover, the 1961 principles provide two important, interconnected issues. Firstly the requested state's right to seek information and clarification from the requesting State as to the nature of offence for which extradition has been requested in order to determine whether the offence is of political character or not. Secondary, the draft also states that, "in cases where the person sought to be extradited submits prima facie evidence that his offence is of a political character, the burden of proving the opposite lies on the requesting state".

These provisions are extremely important in complementing and strengthening the genuine instances of political offences and therefore should form an integral part of this article.

\section{Article 4 : Extradition of a National}

(1) Extradition of a national of the requested State shall be a matter of discretion for the requested state.

(2) In the event of refusing to extradite the fugitive who is a national, the requested State shall submit the case to the competent authorities for prosecution and inform the requesting State of the result.

(3) In case a national of the requested state is prosecuted and is being punished by the requesting state, the States Parties shall negotiate to the effect that the fugitive may serve his sentence in the State of which the fugitive is national.

\section{Commentary}

The general practice relating to the extradition of nationals is the strict application of non-extradition. The whole of civil law States and socialist States very zealously uphold this principle. ${ }^{34}$ Even at the peak of the drug offensive by the Mafia some governments were unable unilaterally to decide whether nationals could be extradited to foreign states and were forced to place the matter for referendum before citizens. ${ }^{35}$

Within the Commonwealth, although there is no strict rule regarding the extradition of nationals, there are instances where extradition of nationals is pre-empted by assuming jurisdiction over the offender irrespective of the place of commission of the offence. This is based on the 'active nationality' principle. Inter alia, United Kingdom law has provided for jurisdiction over its nationals in respect of treason, murder, bigamy and breaches of official secrets acts wherever committed. ${ }^{36}$ Other Commonwealth members have also enacted legislation providing for jurisdiction over nationals for their crimes committed outside their territories. It might be paradoxical that while the common law system practices the territoriality principle re- 
garding criminal jurisdiction (including the foreigners committing crimes) they nevertheless seek to exercise jurisdiction over their own nationals if they happen to commit certain classes of crimes in other jurisdictions under the plea of active nationality principle.

Assumption of jurisdiction over one's own nationals for crimes committed beyond its jurisdiction indicates the intention of some states that these crimes are not extraditable. It could therefore lead to controversy if a national is sought to be extradited by other states.

The rationale given when a national of a requesting state is prosecuted under the active nationality principle for an offence committed abroad, is that the accused is well within his national legal system, culture and language. This is not possible in the case of nationals of the requested state being extradited to the requesting State. Here, the fugitive might face hardships due to the differences in cultural, linguistic and professional aspects which would place him in a disadvantageous position in the requesting state.

There is however, a concern that if the nationals of the requested State are not extradited, the end of justice might be defeated and the validity of the principle of territorial jurisdiction would be jeopardized. The necessary evidence to prosecute may not be easily available. Such contingencies are therefore sought to be tackled by demanding the extradition of nationals on the basis of reciprocity. ${ }^{37}$ On the other hand reciprocity could be a basis for prosecuting nationals in their own national systems especially when the offence for which extradition is sought happens to be one of double criminality i.e. crime under both the jurisdictions. It, nevertheless, should be mentioned that the major trend in the world is to prosecute the nationals by the requested State itself rather than extraditing them.

While the civil law and socialist legal systems are clear, the trend within the Commonwealth is unclear and the question is regarded as a matter of discretion of the parties to an extradition arrangement. ${ }^{38}$ This divergence may be due to historical reasons. Before the emergence of independent States within the Commonwealth, extradition was a matter merely of transferring the fugitive from one part of the empire to another part for reasons of expediency of administering a vast empire, since the issue of nationality did not arise in most cases. Commonwealth nations, however, today have independent nationality laws, constitutional safeguards for individuals during a trial etc. In fact some courts, such as Nigeria, are precluded by their constitution from extraditing nationals but accept the obligation, when so refusing, to consider initiating prosecution locally. Article 4(3) is provided to facilitate the rights enjoyed by the fugitive as well as his family members to enable the convicted person to serve his term within his country in a familiar surrounding. The transfer of the fugitive to serve the sentence in his own State serves the purpose of meeting the demands and concerns of both the requesting and requested state.

The draft articles, therefore, while providing discretion in the matter of extraditing the national of a contracting party, seeks to make it obligatory to prosecute the fugitive locally in case there is no extradition of the national. This would therefore provide a viable compromise between the civil law approach and the practice of the Commonwealth countries.

\section{Article 5 : Grounds for Non Extradition Other than Political Offence Exception}

Extradition may be denied in the following circumstances :

1. Extradition shall not be granted for purely military offences.

2. When the prosecution or punishment is barred by the statute of limitations according to the laws of the requesting State or the requested State (Prior to the presentation of the request for extradition).

3. When the person sought (is to be tried) before an extraordinary or ad hoc tribunal of the requesting state. 
4. When there is reason to believe that extradition is sought in fact for the purpose of prosecuting or punishing the person on account of his race, religion, nationality or political opinions.

5. If the offence for which extradition is sought is of a trivial nature.

6. If the allegation against the fugitive is not made in good faith or in the interests of justice.

7. Any other sufficient humanitarian consideration that warrant the denial of extradition such as acute ill health, physical frailty etc. (In this case the requesting State could postpone the request until such time is required for the fitness of the fugitive).

\section{Commentary}

The grounds on which extradition could be denied as stated in the draft article have been in usage under various legal systems with regard to extradition. The multilateral and regional extradition arrangements traditionally contain a fairly acceptable list of such grounds for denial of extradition. The draft article has been given the present shape after incorporating the familiar grounds from existing regional extradition arrangements. Thus, the draft article might appear to be a longer one than other schemes. However, in view of the emerging universal consensus on the method of prescribing an extraditable offence, efforts should be made to unify the trends regarding other areas of extradition such as the present one.

The grounds for denial of extradition as propounded by the present article might be familiar within the Asian-African region and accordingly warrant no explanation. However, clause (3) which speaks of the possible trial before an ad hoc tribunal of the requesting State is a completely new one that was not deliberated within the Committee when adopting the 1961 principles. Modern extradition arrangements such as the Inter-American Extradition Treaty ${ }^{39}$ preclude categorically extradition, on that ground.

In view of the increasing universal concern for the human rights of individuals and particularly the relevance of human rights to criminal procedure and justice, there is a visible trend within Europe to preclude extradition if the procedural law in the requesting State is not in conformity with the European Convention on Human Rights. ${ }^{40}$ Like the Inter-American Convention, a number of European States do not extradite a fugitive if he is to be tried before an extraordinary or ad hoc tribunal. ${ }^{41}$ This is perhaps due to the fear that such extraordinary or ad hoc prosecution mechanisms are generally created with such powers the exercise of which may not correspond with the basic principles of natural justice or the fundamental norms of criminal jurisprudence. Further, more often than not, such tribunals are also created with an element of subjectivism, sometimes ultra vires of the requesting state's own constitution.

\section{Article 6 : Speciality Rule}

(1) The requesting State shall not try or punish the fugitive extradited except for the offence for which he was extradited.

(2) In the event of the requesting State trying or punishing the fugitive for other offences that are likely to be directly related, it shall do so only with the consent of the requested State.

\section{Commentary}

The speciality rule, like the double criminality rule, is a well respected tenet of the extradition process among States of all legal systems. ${ }^{42}$ The rule seeks the compliance by the requesting State to try or punish the fugitive only for the offence for which the fugitive was extradited. The requesting State is prohibited from using the opportunity of an extradition grant to prosecute for other offences which may or 
may not have been extraditable. For any other offence allegedly committed by the fugitive the requesting State is obligated to make an altogether new request.

All the major extradition arrangements, such as the Commonwealth Scheme, the Inter-American Convention on Extradition, 1981, the European Convention on Extradition, 1957, provide specially for the speciality rule. Most of the bilateral treaties and municipal legislations also reflect the same.

However, slight modifications are taking place with regard to the speciality rule, without questioning the fundamental validity of the rule. For instance, within Europe there seems to be a trend that the requesting State may without prior consent of the requested State, prosecute for an offence even if the description of the offence charged is altered in the course of the proceedings, provided that the offence is based on the same facts and constitutes itself a returnable offence. There are extradition treaties that require prior consent only if, for the offence in its altered description, a higher minimum punishment is fixed than for the offence for which extradition was granted. ${ }^{43}$

The Committee's 1961 principles have put adequate emphasis on the speciality rule in article 9 . The present draft article, however, while retaining essentially the same content, is divided into separate clauses: clause (1) addresses positively the need to uphold the speciality rule and clause (2) provides a procedure in case the requesting State wishes to try or punish the fugitive on a directly related offence other than the one for which the extradition was sought. In other words, clause (2) still prohibits a State's clandestine effort to try the fugitive for other offences.

\section{Article 7 : Double Jeopardy (Non bis in idem)}

Extradition shall be refused if the offence in respect of which extradition is sought is under investigation in the requested State or the person sought to be extradited has already been tried and discharged or punished or is still under trial in the requested State for the offence for which extradition is sought.

\section{Commentary}

The principle of non bis in idem is primarily applicable in the domestic penal law which prohibits the courts from trying a person twice for the same offence. In this sense it has been recognized as part of the human rights. ${ }^{44}$ While all the extradition treaties inevitably provide for this basic rule, some variations in its application have been noticed. Such variations normally relate, on the one hand, to the question whether the double jeopardy rule is to be applied only with regard to decisions of the other contracting State, or also with regard to those of third States and on the other hand, whether all or only certain judicial decisions are to be taken into consideration when deciding upon a request for extradition. ${ }^{45}$

The legal arrangements and the practice of most of the member States of the Committee contain provisions against double jeopardy for the same act. See for instance, the Criminal Procedure Code of Iraq, the Iraqi-Egyptian Treaty of 1941, the Law of the United Arab Republic (as understood in 1961), the Egypt-Iraq Agreement of 1931, the laws of Japan and Indonesia. The extradition agreement concluded between the countries of the League of Arab States contains the principle non bis in idem. ${ }^{46}$ Moreover, the 1961 rule on this principle was unanimously adopted by the members of the Committee. In view of its universality as well as acceptability within the Committee the same article has been retained.

\section{Article 8 : Capital Punishment}

If the offence for which extradition is requested is punishable by death under the law of a requesting State and the law of the requested State does not provide such penalty, the requested State has the discretion to refuse extradition, unless the re- 
questing State gives such guarantee which the requested State considers sufficient that the death penalty will not be carried out.

\section{Commentary}

The question of capital punishment has generated a good deal of controversy since the Second World War with regard to its nature as a punishment.

Although legislation in many countries prescribe the death penalty for capital offences, there is a trend at the global level seeking to abolish capital punishment. A number of other States, however, have enlarged the category of capital offences. As far as the extradition arrangements are concerned the trend is clearly towards refusal to grant extradition where the fugitive is likely to be awarded the death penalty if the requested State does not itself provide for the death penalty. Extradition is granted under such circumstances only after the guarantee of the requesting State that in case the death penalty is awarded it will not be carried out. The trend has been explicitly provided for under some modern extradition treaties. For instance, both the European Extradition Treaty ${ }^{47}$ and the Inter-American Convention on Extradition ${ }^{48}$ uphold the right of the requested State to refuse extradition in case the requesting State does not assure the commutation of the death sentence. The Commonwealth Scheme has, however, left the present question as a matter of discretion to the parties to decide whether to grant extradition or not in case where the fugitive is likely to suffer the death penalty. It has followed, in principle, the European Convention on Extradition. ${ }^{49}$

However, within the Commonwealth where several member States keep capital punishment in their statute books, still there is a trend toward following the European Convention. ${ }^{50}$ States that still provide for the death sentence in their criminal law could, while dealing with the extradition of a fugitive who is likely to face the death sentence in the requesting State, keep in mind the relevant provisions of Article 6 of the International Covenant on Civil and Political Rights which states, inter alia:

"Any one sentenced to death shall have the right to seek pardon or commutation of the sentence. Amnesty, pardon or commutation of the sentence of death may be granted in all cases."

"Sentence of death shall not be imposed for crimes committed by persons below eighteen years of age and shall not be carried out on pregnant women."

The Committee's 1961 principles have not addressed this question. It is opportune to consider the issue in light of the experiences of existing major regional extradition arrangements.

\section{Article 9 : Prerequisites of a Request}

The requisition for extradition shall be made through diplomatic channel or any other appropriate channel in writing and accompanied by:

(a) information concerning the identity, description, nationality and location of the person sought;

(b) a statement of the offences for which extradition is sought, the time and place of commission, their legal descriptions, probable punishment and a reference to the relevant legal provisions with utmost accuracy;

(c) the original or authenticated copy of the conviction and sentence or detention order passed by competent judicial authority and immediately enforceable or of the warrant of arrest or other having the same effect and issued in accordance with the procedure laid down in the law of the requesting State;

(d) a copy of the statute of limitation governing prosecution and punishment. 


\section{Commentary}

Traditionally, an extradition request which is an act between Governments of sovereign States is made through the diplomatic channel. However, in view of its time-consuming nature the practice relating to the request has witnessed a recent trend in which communication could be made directly between the concerned ministries of both the requesting and requested States. For example article 12 of the European Convention on Extradition provides:

"The request shall be in writing and shall be communicated through the diplomatic channel. Other means of communication may be arranged by direct agreement between two or more parties."

Regional extradition treaties such as the Inter-American Extradition Convention have even provided for a situation wherein there may not be any diplomatic relations between States. Thus the relevant provision states:

"The request for extradition shall be made by the diplomatic agent, or if none is present by its consular officer, or, when appropriate, by the diplomatic agent of a third State to which is entrusted, with the consent of the government of the requested State, the representation and protection of the interests of the requesting State. The request may also be made directly from government to government in accordance with such procedure as the governments concerned may agree upon. ${ }^{51}$

Thus, it is discernible that the traditional diplomatic channel of communications is complemented by new methods. The guidelines of the Committee's 1961 principles, while providing that "the requisition shall . . .. be submitted normally through diplomatic channel" did not envisage other possible modes of communication between the requesting and the requested States. Therefore the present article provides the words, "or any other appropriate channel" with a view to providing the broadest possible channels of communications.

The other requisites for an extradition request have been similar in almost all the major extradition arrangements, though there may happen to be some trivial differences. Basic requirements, however, are two. If extradition is sought for prosecution, the basic document is a warrant of arrest signed by the competent judicial authority of the requesting State. If the fugitive is sought for imprisonment as a consequence of an indictment, a certified copy of the final judgment must be submitted. As far as the texts of the relevant legal provisions are concerned, the minimum requirement is to submit the text of the substantial penal law that was breached. Keeping in mind that the modern extradition arrangements preclude extradition if the offender could not be prosecuted for lapse of the limitation period, which aspect also finds a place in the present draft articles, there is a need for the requesting State to produce a copy of the statute of limitation governing the criminal prosecution and punishment.

\section{Supplementary Information or Evidence}

If the evidence or information submitted by the requesting State in support of a request is found to be insufficient, the requested State may ask the requesting State to provide supplementary information or evidence as it may consider necessary to finalise a decision on the request. The requested State may also set a time limit for the receipt of such supplementary information evidence, and if the requesting State fails to comply with the subsequent requirement within the prescribed time the requested State may set free the fugitive. 


\section{Commentary}

It is not always possible that the particulars accompanying the extradition request be correct or adequate at the first instance itself. Therefore, there is a need to provide for a mechanism to enable the requested State to demand supplementary information from the requesting State on all aspects of the request with a sole purpose of ascertaining the facts that are necessary to extradite a fugitive. All the modern extradition arrangements provide for seeking supplementary information. ${ }^{52}$ However, in the event of extradition being refused the requested state has to, without fail, give reasons for the same.

\section{Article 10 : Evidential Requirement}

(1) Extradition shall not be granted unless the competent authorities of the requested State are satisfied that the material furnished before them establishes (sufficient evidence) (prima facie case) that the fugitive has committed an offence in the requesting State.

(2) When the person sought is already convicted for an offence in the requesting State the requesting State shall establish that he was convicted by competent judicial authorities in respect of an extraditable offence within the jurisdiction of the requesting State and that he has not served his sentence in accordance with the laws of the requesting State.

\section{Commentary}

Besides general rules, which are more or less a common feature of all extradition treaties, owing to the particular situation of the countries involved, there are sometimes specific additional requirements that needed to be fulfilled. One such requirement is the prerequisite of establishing a prima facie case by the requesting state against the fugitive offender.

As regards this requirement, in case where extradition is requested for the purpose of prosecution rather than for execution of punishment following conviction, the approaches in the common law and civil law systems are divergent. The question arises in the former case whether or not an extradition request must be supported by further evidence if it is based solely on a warrant of arrest.

In most common-law countries, the establishment of a prime facie case is traditionally a paramount requirement if the extradition of an accused person is sought for the purposes of prosecution. According to typical extradition treaties entered into by common law countries, prima facie evidence is "such evidence as, according to the law of the requested party, would justify his (i.e. accused person) committal for trial if the offences had been committed in the territory of the requested party. ${ }^{53}$

Most common law countries apply particularly a strict approach in this respect. The basic idea is to ensure equality of treatment for all persons who stand before the court accused of an offence wherever this was committed. ${ }^{54}$

The typical approach of civil law countries on the other had may be characterized as a common understanding that extradition is a preliminary auxiliary system of bringing an offender to justice. ${ }^{55}$ According to this view, it is up to the court of the requesting State to take and evaluate evidence. The requested State is not called upon to investigate the subject and its authorities may content themselves with the fact that valid judicial warrant of arrest exists, based on an extraditable offence and that the contractually stipulated State has grounds for doubting the reasons given for an extradition request. ${ }^{56}$

The differences in the rule of evidence between common law and civil law countries have made the extradition proceedings very difficult. It seems that a high percentage of extradition requests submitted by civil law countries to common law countries fail for these formal reasons. ${ }^{57}$ Some countries have decided that no further extradition request should be made where a prima facie case needs to be estab- 
lished. ${ }^{58}$ In fact Spain, a civil law country, has already terminated its extradition treaty with the United Kingdom, due to this reason. ${ }^{59}$

Even though within the common law system, wherein the requirement of prime facie case has been zealously guarded, there are radical views questioning the validity of this rule. A case in point is the position taken by Australia within the Commonwealth. There are, however, trends within England also which argue for the abolition of the requirement. ${ }^{60}$ Two most important common law countries India and Canada have not adhered to the prima facie requirement so stringently in a recent agreement. ${ }^{61}$ Though such trends are discernible in bilateral and municipal settings, when it comes to the Commonwealth as such, the prima facie requirement has been largely retained.

On the other hand, the civil law countries who follow the inquisitorial method in criminal prosecution do not require the establishment of a prima facie case before granting an extradition request. Reference may be made to Article 12 of the European Convention on Extradition which makes no reference to the prima facie case. However, Article 13 enables the requested State to seek any supplementary information which is thought to be necessary in order to reach a decision. Although there is no express provision for contracting States to provide a prima facie case, some States have nevertheless, on acceding to the Convention, made a reservation on this point. Israel for instance insists upon prima facie case in all cases, whereas Norway and Denmark reserve the right to ask for such evidence in any particular case. The Federal Republic of Germany is also in the process of a radical change in this regard. Following recent Court decisions, Article 10(2) of the new German Statute requires documents establishing a prima facie case if in the circumstances of the case there is reasonable doubt whether the requested person has in fact committed the offence.

Thus, the rule relating to prima facie requirement within the common law and civil law system is changing but no distinct developments are taking place in both systems. Perhaps this is another area in which there could be efforts to harmonize the evidential requirements. One possible compromise is to make the requirement of prima facie case discretionary.

The Committee's 1961 principles, however, provided specifically for the establishment of prima facie case in Articles 16 and 17. The practice in the member countries (as of 1961) is that a fugitive offender would be discharged if a prima facie case is not made out against him. There was a unanimity within the Committee then on this point. The draft article seeks to retain the requirement of prima facie case. However, if any change is contemplated to reduce the rigors of this requirement, it should seek to strike a balance between the requirement of an absolute prima facie case and the presentation of a simple warrant of arrest. This is essential since the requested state should be in a position to satisfy itself before extraditing a fugitive. That is the intent of the inclusion of the words 'sufficient evidence' in parentheses in the draft articles.

\section{Article 11 : Surrender}

(1) The competent authorities of the requested State shall take the necessary steps to enable the requesting State to take away the accused.

(2) The requesting State shall be informed of the place and date of surrender and of the length of time for which the fugitive will be detained for the purposes of surrender.

(3) The requested State may release the fugitive in question, if the requesting State fails to take custody of the fugitive within the prescribed time from the day of notification to the requesting State. 
(4) If circumstances beyond their control prevent either of the States from surrendering or taking over the fugitive within the time, the States shall agree on a new date for surrender.

\section{Article 12 : Reply by the Requested State}

The requested state shall inform the requesting state through diplomatic channel or other appropriate channel, in writing of its decision on the request for extradition. If the request for extradition is rejected, the reasons shall be stated.

\section{Commentary}

Once a request has been submitted to the requested state, the requested state has to act on it. The decision to grant or refuse extradition shall be made in writing and shall be transmitted through the same channel through which the requesting State made the request. In the event of extradition being refused the requested State has to give reasons for its decision.

\section{Article 13 : Concurrent Requests}

(1) If there are concurrent requests for extradition in respect of the same person the requested State shall have the discretion to decide upon the priority of requests.

(2) The requested State, while doing so, shall take into account all the circumstances and especially the relative gravity of the offences, place of commission, order of requests, penalty to be imposed and the nationality of the person claimed.

\section{Commentary}

It is possible that several States could make concurrent requests for the extradition of the same fugitive who has committed extraditable offences in the territories of all the requesting States. The major trend relating to this point is that the requested State shall have the discretion to decide as to which of the requesting States the fugitive shall he surrendered. However, the requested State is expected to take into account certain factors in exercising its discretion. Such factors according to the major extradition arrangements currently in force include the relative gravity of the offences, places of commission, order of requests and the nationality of the person. The requested state may also take into account other necessary circumstances before deciding. As highlighted by the Inter-American Extradition Convention on this question :

\footnotetext{
"When extradition is requested for the same offence, the requested State shall give preference to the request of the State in which the offence was committed. If the requests are for different offences, preference shall be given to the State seeking the individual for the offence punishable by the most severe penalty, in accordance with the laws of the requested State. If the requests involve different offences that the requested State considers to be of equal gravity, preference shall be determined by the order in which requests are received".
}

\section{Article 14 : Seizure of Property, Articles etc.}

Articles seized which were in the possession of the fugitive, at the time of his arrest, and which may be used as proof of the offence shall be delivered to the requesting State at the time of the actual extradition.

\section{Commentary}

While arresting the fugitive it is the duty of the requested State to seize all articles and objects that are found with him. This is essential since they might be needed during the committal proceedings in the requesting State as evidentiary objects. It is also the duty of the requested State to deliver all such articles seized from 
the fugitive to the requesting State. In view of the unanimity that prevails within the Committee and elsewhere the present draft article is almost identical to that of the 1961 principles on this matter.

\section{Article 15 : Abduction of the Fugitive}

If the fugitive is abducted from the requested State by the agents of the requesting State, the requested state shall be entitled to demand the return of the fugitive.

\section{Commentary}

The question of abduction instead of formal extradition of a fugitive by the agents of the requesting State came into the limelight after the seizure on May 11, 1960 of Adolf Eichmann by "private" Israeli citizens in Argentina and his transportation to Israel on an Israeli aircraft to face trial as a Nazi war criminal. ${ }^{62}$ It may, however, be noted that the extradition of a fugitive is a prerogative of the asylum/requested state and that the requesting State, i.e. the State which seeks jurisdiction over the fugitive, has an obligation to seek the consent of the territorial State where the fugitive is hiding. It is not a question of protection of the fugitive by the requested State, but of its prerogative to have a say on the matters that take place within its territory. That is why the draft article makes it explicit that the requested State still has the right to demand the custody of the fugitive who might have been abducted by force by the agents of the requesting State.

\section{Article 16 : Deferral of Surrender}

When the fugitive is being tried or is serving a sentence in the requested State for an offence other than the one for which extradition is requested, surrender may be postponed until he is set free either through acquittal, completed service or commutation of sentence, dismissal, pardon or grace. Civil suit that may be pending against the fugitive in the requested State would not, however, defer his surrender.

\section{Commentary}

There might be a situation wherein the request of extradition may be made to procure a fugitive who is on trial in the requested State. Under such circumstances, it is the practice to wait for the final disposal of the on-going trial by the requested State. Therefore, the surrender could be postponed until the final ruling of the case. However, if the trial in the requested State takes unduly long time, the States concerned could arrive at a decision through negotiation as to whether to postpone the case of the fugitive to stand trial in the requesting state. Postponement or deferral of extradition is permissible only in a criminal case but not in civil cases.

\section{Article 17 : Provisional Arrest}

In case of urgency the requesting State may request the provisional arrest of the fugitive and the requested State may do so and keep the fugitive in custody.

\section{Commentary}

Normally the fugitive is kept in custody after committal proceedings are over and the decision has been taken that the fugitive shall be extradited. However, in urgent cases the custody may precede the committal proceedings. Although the requesting State may request the requested state to do so, ultimately it is at the discretion of the requested state to keep the fugitive in custody or not before committal. This matter, however, seems to be analogical to the preventive custody and accordingly would depend upon the provisions of relevant laws. 


\section{Article 18: Urgent Requests}

(1) In urgent cases requests for extradition may be made by post, telegram, or telephone, provided that the requests include a short account of the offence, a notification that a warrant of arrest has been issued by the competent authority and that extradition shall be requested through diplomatic channel or other appropriate channels.

(2) The requested State may, if necessary, arrest and detain the fugitive for a period not exceeding thirty days, after which he shall be released unless the written request accompanied by the necessary details of information is received.

(3) If the request is made by post, telegram or telephone the requested State shall have the right to ascertain the request by seeking a written request from the requesting State.

\section{Commentary}

This article addresses the possible modes of communication relating to urgent requests for extradition. Similar provision is found in almost all the modern extradition arrangements although with slight variations. In the case of urgency it may not be possible to adopt all the formalities or prerequisites of a normal extradition request. That is why it may provide for the use of simpler communication means such as post, telegraph, telephone and other modern communication means. Such requests need not even be sent through diplomatic channels and the governments could communicate directly at ministerial level. However, it may be pointed out that urgent requests would result only in the provisional arrest of the fugitive and within the time limit set by the requested State. The requesting State shall have to make a proper and formal request in order to effect the surrender of the fugitive. The requested state has the right to set free the fugitive from provisional arrest if the requesting state has not presented the necessary details of information within the time set by the former.

\section{Article 19 : Extradition of a Third State's National}

If the fugitive whose extradition is requested is not a national of the requesting State, the requested State may notify the State of which the fugitive is a national of that request as soon as it is received in order to enable the said State to defend him if necessary.

\section{Commentary}

There are instances in which a State may be requested to surrender the fugitive who may be the national of a third State, having committed an extraditable offence within the territory of the requesting State. This is slightly different from concurrent requests wherein the [national] State of the fugitive besides the requesting State may request the extradition on the basis of the active nationality principle. Here the situation may be that the national state may not be aware that one of its nationals having committed an extraditable crime in one country has fled to a third country. Although the requested State in whose territory the fugitive is found has the right to decide on the question of surrender, it is, however, in the interests of the comity of nations, to notify the national State of the fugitive, giving it an opportunity to be aware of the matter and if possible, to defend the fugitive. Those States who subscribe to the non-extradition of their nationals may find such provision useful.

\section{Article 20 : Re-extradition}

The requesting State shall not without the consent of the requested State, surrender the fugitive to a third State in respect of an offence committed before the surrender. 


\section{Commentary}

The basic presumption of extradition law is that the fugitive is surrendered to the requesting State to stand trial or serve sentence only for the specific offence or sentence for which he was sought to be extradited. Therefore, the requesting State has an obligation to obtain the consent of the requested State if there is an intention to hand over the fugitive to a third country. The requested State has the right to decide the fate of the fugitive in relation to other offences that he might have committed other than the one for which he was surrendered. Such provision is found in the European Convention on Extradition, ${ }^{63}$ and it may be adopted by the AALCC.

\section{Article 21 : Procedural Law}

The procedure with regard to extradition, provisional arrest or committal before the judicial authorities shall be in accordance with the law of the requested State.

\section{Commentary}

Basically extradition is a domestic matter and analogical to a trial under the domestic law, although it has an international element in as much as the request for surrender comes from another State. However, the extradition process relating to provisional arrest, committal, evidence will have to be in accordance with the law of the requested State.

\section{Article 22 : Simplified Extradition (Waiver of Committal Proceedings)}

The requested State may grant extradition without a formal extradition proceeding if the fugitive sought irrevocably consents in writing to the extradition after being advised by a judge or other competent authority of his right to a formal extradition proceeding and the protection afforded by such proceeding.

\section{Commentary}

There is a possibility where the whole process of committal proceedings might become superfluous in view of the possibility that the fugitive may not contest the decision to surrender him. This amounts to a virtual waiver of committal proceedings by the fugitive and of course with the full knowledge of the consequences of such a voluntarism. Extradition arrangements such as the Inter-American Convention and the Commonwealth Scheme provide for such waiver of committal procedure by the fugitive. It is, however, the duty of the requested State to advise him of his rights as a fugitive.

\section{Article 23 : Rights of the Fugitive}

The fugitive sought shall, during the process of extradition, enjoy all the legal rights and guarantees granted by the law of that [the requested] State.

The fugitive shall be assisted by legal counsel and if the official language of the requested State is other than his mother tongue, he shall also be assisted by an interpreter free of cost.

\section{Commentary}

This article guarantees the equality before the law of the requested State if he decides to contest the decision to extradite him. The requested State is obliged in such cases to provide the fugitive with adequate legal assistance, for instance, the service of a legal counsel and an interpreter free of cost. This would guarantee the fugitive impartiality in the requested State. 


\section{Article 24 : Costs of Extradition}

The requesting State shall bear all expenses incurred in the execution of the request, and if the fugitive is discharged or acquitted, the said State shall bear the expenses necessary for his return to the requested state.

\section{Commentary}

The requesting state is expected to bear the expenses that might accrue in the execution of an extradition. for instance, the cost of conveyance, transport etc. from the territory of the requested State to the territory of the requesting State. In the event of the fugitive being acquitted or discharged the requesting State shall bear the expenses for the fugitive's return to the requested State.

\section{NOTES:}

1 See the agreement reached within the AALCC during its fourth session 1961. AsianAfrican Legal Consultative Committee, Report of the Fourth Session 1961 p. 23. Also see Gerhard von Glahn, Law Among Nations: An Introduction to Public International Law (second edition), The MacMillan Company, London 1970 p. 252; Ian Brownlie, Principles of Public International Law third edition 1979).

${ }^{2}$ Ibid., AALCC Report of the Fourth Session.

${ }^{3}$ For instance, the United Kingdom Extradition Acts 1870, 1873, 1906 and 1932, Belgian law of 1933. Extradition Acts of most of the Commonwealth countries which are based on the British model provide for enumerative method.

${ }^{4}$ For example, Extradition Act of India 1961, Extradition Act of Nigeria 1966. The 1966 Commonwealth Scheme Relating to the Rendition of Fugitive Offenders until recently provided for the list approach.

${ }^{5}$ Japan-US Extradition Treaty signed on March 3, 1978 and entered into force on March 26, 1980. This Treaty adopts the enumerative method listing out 47 offences as extraditable ones. See the Japanese Annual of International Law, No. 24, 1981, pp. 263-271.

${ }^{6}$ For a brief survey of the historical evolution of the enumerative and eliminative methods of qualifying extraditable offences and the difficulties involved in adopting the enumerative method, see Extradition for Drugs Related Offences, $\boldsymbol{A}$ Study of Existing Extradition Practices and Suggested Guidelines for use in Concluding Extradition Treaties (United Nations Sales No. E.Xl 6, pp. 22-25 1985).

${ }^{7}$ Ibid., at p. 22.

${ }^{8}$ Ibid.; similar views were expressed by the Indian delegation to the 28th session of the AALCC held in Nairobi. For details see Verbatim Records of the 28th Session (Nairobi) 13th to 18th Feb. 1989, pp. 373-378.

${ }^{9}$ Approved by the Council of the League of Arab States on 14 September 1952, entered into force on 23 August 1954. For text see League of Arab States, A Collection of Treaties No. 95(1978).

${ }^{10}$ Signed on 13 December 1957; entered into force on 18 April 1980. See European Treaty Series No. 24, United Nations Treaty Series Vol. 359, No. 5196.

${ }^{11}$ Signed in 1961 by Benin, Burkina Faso, Cameroon, Central African Republic, Chad, Congo, Gabon, Ivory Coast, Madagascar, Mauritania, Niger and Senegal.

${ }^{12}$ Entered into force on 11 September 1967.

${ }^{13}$ Signed on 25 Feb. 1981 by Bolivia. Chile, Costa Rica, Dominican Republic, Ecuador, El Salvador, Guatemala, Haiti, Nicaragua, Panama, Uruguay and Venezuela. For the text see $I n$ ternational Legal Materials Vol. 20, No. 31981 pp. 723-728.

${ }^{14}$ Article 2(2) of the Revised Scheme adopted at the Meeting of the Commonwealth Law Ministers at Harare, 1986. For the text see Commonwealth Law Bulletin Vol. 12 No. 4 October 1986, pp. 1124-1130.

${ }^{15}$ Article 3 stipulates that "An extradition offence is committed when the conduct of the person whose extradition is sought constitutes an offence punishable by a term of imprisonment for a period of more then one year", Indian Journal of International Law, Vol. 27 No. 2 \& 3, AprilSep., 1987, p. 279. 
${ }^{16}$ For the text of the Convention see International Legal Materials 1978, p. 113.

${ }^{17}$ Ibid.

${ }^{18}$ International Legal Materials, 1977, p. 1236.

${ }^{19}$ International Legal Materials, Vol. 21, pp. 886-1982.

${ }^{20}$ See Commonwealth Law Bulletin, Vol. 9 No. 1, 1983, p. 285.

${ }^{21}$ United Nations Treaty Series, Vol. 704 No. 10106, p. 219.

${ }^{22}$ United Nations Treaty Series, Vol. 860, No. 12325, p. 106.

${ }^{23}$ United States Treaties and other International Agreements Vol. 24 (1973) p. 268.

${ }^{24}$ United Nations Treaty Series Vol. 1035 No. 15410 p. 167.

${ }^{25}$ Signed at Washington in February 1971 by Colombia, Costa Rica, Dominican Republic, Jamaica, Honduras. Mexico, Nicaragua, Panama, El Salvador, Trinidad and Tobago, USA, Uruguay and Venezuela.

${ }^{26}$ See International Legal Materials, Vol. 15, 1976, p. 1272.

${ }^{27}$ See International Legal Materials, Vol. 19, 1980. p. 325.

${ }^{28}$ Indian Journal of International Law, Vol. 27, No. 2 \& 3 April-September 1987, pp. 315-318.

${ }^{29}$ International Legal Materials, Vol. 12, 1973, p. 370.

${ }^{30}$ Indian Journal of International Law, Vol. 23, 1987, pp. 279-294.

${ }^{31}$ Single Convention on Narcotic Drugs 1961, as amended by the 1972 Protocol, and the 1971 Convention on Psychotropic Substances.

${ }^{32}$ For the meaning and evolution of the political offence concept see : Shearer, Extradition in International Law (1971). However, the courts in England and other common law jurisdictions approach the definition of political offence from case to case basing themselves on precedents. Some of the celebrated cases in this regard are : Re Castioni (1891) 1 Q.B.149, In Re Meunier (1894) 2 Q.B. 415, R. .v. Governor of Brixton Prison, ex p. Kolczynski (1955) QB 540, Schiraks v. Government of Israel (1964) A.C. 556; etc.

${ }^{33}$ See Article I of SAARC Convention; for text see Indian Journal of International Law Vol. 27,1987 at p. 316.

${ }^{34}$ For the position of socialist countries, for instance, Article 63 of Treaty Between the Mongolian People's Republic and the People's Republic of Bulgaria Concerning the Provision of Legal Assistance in Civil, Family and Criminal Cases, states: "Extradition shall be precluded if: (a) The offence was committed by a national of the Contracting Party applied to". UNTS Vol. 6771969 at p. 172. Also see Article 55 of the Treaty between Hungary and Mongolia, UNTS Vol. 678, 1969 at p. 176. For the position of civil law countries, see Treaty on Extradition Between Brazil and Argentina 1961. Article 1 states: "1. However, should the person in question be a national of the State to which application is made, the said State shall not be obliged to surrender him. In such cases, where extradition has been refused, the person shall be proceeded against and tried in the State to which application is made for the act which gives rise to the application for extradition, unless such act is not punishable under the laws of that State. 2. In such cases the applicant Government shall supply the necessary evidence for prosecution and trial of the accused and it shall be incumbent upon the other government to communicate to it the final sentence or decision in respect of the case. The Constitution of Guatemala vide Article 61 provides that "No Guatemalan shall be handed over to a foreign government for trial or punishment except for crimes covered by international treaties in force in Guatemala".

${ }^{35}$ The Colombian Government of President Virgilio Braco is putting the question of whether or not suspected Colombian traffickers should be extradited to the United States for trial to a referendum. Times of India (New Delhi) Oct 7, 1989.

${ }^{36}$ Ian Browlie, Principles of Public International Law (2nd Edition 1979) p. 300.

${ }^{37}$ E.g. Indian statement on this point at the 28th session of the AALCC, Verbatim Records $p$. 377.

${ }^{38}$ Clause 2 of Annex 2 of the Commonwealth Scheme Relating to Rendition of Fugitive Offenders states as follows:

(1) The return of a fugitive offender who is a national or permanent resident of that part of the Commonwealth in which he is found (a) may be precluded by law, or (b) may be refused by the competent executive authority, provided that return will not be so refused if the fugitive is also a national of a part of the Commonwealth to which his return is requested. 
(2) For the purposes of this paragraph a fugitive shall be treated as a national of a part of the Commonwealth if that part consists of, or include (a) A commonwealth country of which he is a citizen or, (b) A country or territory his connection with which determines his national status, in either case at the date of the request.

${ }^{39}$ Clause (3) Article 4 of Inter-American Convention on Extradition, which states "When the person sought has been tried or sentenced or is to be tried before an extraordinary or Ad Hoc tribunal of the requesting state". See International Legal Materials, Vol. XX, No. 3, May 1981 at p. 724 .

${ }^{40}$ For example, Swiss and Austrian legislation on the subject have made such provisions. See the paper prepared for the Commonwealth Secretariat by Dr. Torsten E. Stein, in 1982 Review of Commonwealth Extradition Arrangements, Report of a Meeting of Government Representatives, Commonwealth Secretariat 1982 at p. 102.

${ }^{41}$ Ibid.

${ }^{42}$ See Shears, Extradition in international law (1971); Ian Brownlie, Principles of Public International Law, Third Edition (1979), p. 315.

${ }^{43}$ As for instance the extradition treaties between Germany and the United States, and between Germany and Yugoslavia. See Torsten E. Stein, op. cit. p. 101.

${ }^{44}$ See the Seventh Additional Protocol to the European Convention on Human Rights and Fundamental Freedoms.

${ }^{45}$ See Extradition for Drug Related Offences, op. cit. p. 53.

${ }^{46}$ See the Report of AALCC 4th session 1961 p.33.

${ }^{47}$ Article 11 (Capital Punishment) states that "... . If the offence for which extradition is requested is punishable by death under the law of the requesting Party and if in respect of such offence the death penalty is not provided for by the law of the requesting party or is not normally carried out extradition may be refused unless the requesting party gives such assurance which the requested party considers sufficient that the death penalty will not be carried out."

${ }^{48}$ See Article 9 (Penalties Excluded) states: "The States parties shall not grant extradition when the offence in question is punishable in the requesting State by the death penalty, by life imprisonment, or by degrading punishment, unless the requested state has previously obtained from the requesting state, through the diplomatic channel, sufficient assurances that none of the above mentioned penalties will be imposed on the person sought or that, if such penalties are imposed. they will not be enforced.

${ }^{49}$ See Annex 2, paragraph 1 of the Commonwealth Scheme.

${ }^{50}$ For example Article 6 of the Indo-Canadian Extradition Treaty echoes the views of the European Convention on this question.

${ }^{51}$ Article 10, which speaks of 'Transmission of Request', see: International Legal Materials, Vol. 21, pp. 725.

52 Article 12 Inter-American Convention; Article 13 of European Convention on Extradition; Article 10 of Indo-Canadian Extradition Treaty 1987 speaks of 'additional evidence' although effectively it is supplementary information.

${ }^{53}$ See Article VII paragraph 3 of the Extradition Treaty between the United Kingdom of Great Britain and Northern Ireland and the United States of America of June 1972), United Nations Treaty Series Vol. 49, No. 15811.

${ }^{54}$ Review of the Law and Practice of Extradition in the United Kingdom : Report of an Inter-Department working party, in 1982. Review of Commonwealth Extradition Arrangements: Report of a Meeting of Government Representatives, op. cit. pp. 231-262.

${ }^{55}$ Extradition for Drug Related Offences, op. cit. p. 43.

${ }^{56}$ Ibid.

${ }^{57}$ Ibid., p. 42.

${ }^{58}$ Ibid., p. 43.

${ }^{59}$ Ibid.

${ }^{60}$ See 'Green Paper on Extradition' in Commonwealth Law Bulletin, Vol. 11 No.2 , April 1985, pp. 433-499.

${ }^{61}$ Article 9 of (India-Canada Extradition)Treaty states: “Article 9: Extradition Evidence. 1. The evidence submitted in support of the request for extradition shall be admitted in extradition proceedings in the requested State if it purports to be under the stamp or seal of a department, ministry or minister of the requesting State, without proof of the official character of the stamp 
or seal. 2. The evidence referred to in paragraph 1 may include originals or copies of statements, depositions or other evidence purporting to have been taken on oath or affirmation whether taken for the purpose of supporting the request for extradition or for some other purpose. 3. The evidence described in paragraph 2 shall be admissible in extradition proceedings in the requested state, whether sworn or affirmed to in the requesting State, or in some third State" it is clear from the text of this article that there is no obligation on the part of the requesting state to establish a prima facie case and on the other hand any evidence adduced by the requesting state shall be 'extradition evidence'. There is no qualification whatsoever to this 'extradition evidence'.

${ }^{62}$ See Gerhard von Glahn, Law Among Nations: An introduction to Public International Law, Second Edition (1970) pp. 268-269.

${ }^{63}$ Article 15 of the European Convention.

22. After discussion of the item (Report, p. 78) the Committee adopted an essentially procedural resolution (Report, p. 85).

\section{TRADE LAW MATTERS}

\subsection{World Trade Organization (WTO)}

23. The Committee had before it document AALCC/XXXV/MANILA/96/9 entitled "WTO as a Framework Agreement and Code of Conduct for World Trade" containing notes and comments on the main features of the WTO Agreement and its Annexes, and their possible impact on the developing countries:

\section{Background}

1. The Uruguay Round of Multilateral Trade Negotiations, launched in 1986, [was] concluded on 15 April 1994, in Marrakesh (Morocco) with the signing of the Final Act embodying the results of that Round and opening for signature the Agreement establishing the World Trade Organization (WTO) to which all substantive agreements and understandings were annexed, as well as the Ministerial Declarations and Decisions adopted at Marrakesh and the Understanding on Commitments on Financial Services to form an integral part thereof. It was also agreed that the WTO Agreement must be accepted as a package deal without any exception.

2. Of the 125 countries which formally participated in the Uruguay Round, 111 signed the Final Act and -104 signed the WTO Agreement, in many cases with the stipulation that their acceptance was subject to ratification ${ }^{1}$ [fn 1: International Legal Materials Vol. XXXIII No 3 (September 1994) p. 1132. The AALCC Member States signatory to the WTO Agreement include Bahrain, Bangladesh, China, Cyprus, Egypt, Ghana, Indonesia, Kenya, Kuwait, Malaysia, Mauritius, Myanmar, Nigeria, Pakistan, Philippines, Qatar, Senegal, Singapore, Sri Lanka, Tanzania, Thailand, Turkey, Uganda and United Arab Emirates]. Seven countries, Australia, Botswana, Burundi, India, Japan, Republic of Korea and USA, were unable to sign the WTO Agreement because of domestic legislative impediments ${ }^{2}$ [fn 2: Ibid.].

3. The most significant feature of the Final Act was that it represented a single undertaking integrating all the key agreements under one umbrella, i.c. tariffs and now also service commitments as well as substantive trade rules are part of a single package. This was reinforced by the organizational and institutional framework which the WTO Agreement and the WTO, as the international economic organization, provide. 


\section{Impact on Developing Countries}

46. The establishment of the WTO is most likely to result in an overall increase in the scope of obligations for all its members, but developing country members, in particular, will be faced with a dramatic increase in the level of their obligations. This is because they are required to accept all Multilateral Trade Agreements (MTAs) incorporated in Annexes 1. 2 and 3 of the WTO Agreement without any exceptions or reservations, as well as to submit their schedules of concessions on goods and concessions with respect to market access and national treatment for trade in services. They are also required to accept new obligations in the area of trade in services, and, in particular, intellectual property rights. Prior to WTO, few developing countries were parties to the Tokyo Round Codes ${ }^{10}$ [fn 10: As of May 1994, 15 developing countries were parties to the Agreement on Technical Barriers to Trade; 2 to the Agreement on Government Procurement; 13 to the Subsidies Code; 11 to the Anti-Dumping Code; 12 to the Customs Valuation Code; 12 to the Agreement on Import Licensing], but under the revised codes they are required to assume new obligations flowing from them. The very strict conditions for accession to the WTO thus pose a serious challenge to the developing countries.

47. The process of accession will also be much more difficult for those developing countries and economies in transition that are now negotiating their terms of accession to the GATT, as they will need to adopt the new agreements negotiated in the Uruguay Round. For example, they will have to negotiate an 'entry fee' on both goods and services, accept a variety of Agreements that until now had been optional (i.e. most Tokyo Round Codes as revised), and commit themselves to a set of new multilateral rules and disciplines in the areas of agriculture, subsidies and intellectual property rights, among others.

48. The setting up of the WTO, effective from 1 January 1995, represents a significant step towards the full integration of all countries irrespective of their levels of economic development into a global trading system of shared commitments, shared rules and shared opportunities. Unlike the case of the two Bretton Woods institutions, viz. the World Bank and the IMF, in the case of the WTO developing countries have had a role in its evolution and establishment. More than two-thirds of its over 100 members are developing or transition economies, as are the great majority of those in the process of becoming its members ${ }^{11}$ [fn 11: Twenty-one governments are now negotiating accession to GATT or resumption of contracting party status: Albania, Algeria, Armenia, Belarus, Bulgaria, China, Crotia, Ecuador, Estonia, Jordan, Latvia, Lithuania, Moldova, Mongolia, Nepal, Panama, Russian Federation, Saudi Arabia, Slovenia, Taiwan, and Ukraine. Fourteen governments can succeed to contracting party status under Article XXVI: 5(c) (GATT 1947) upon request: Angola, Bahamas, Cambodia, Cape Verde, Equatorial Guinea, Kiribati, Papua New Guinea, Qatar, Sao Tome and Principe, Seychelles, Solomon Islands, Tonga, Tuvalu, and Yemen]. These prospective members include China and Russia whose inclusion in the multilateral system and its rules is vital not only to the completion of the global market but to global stability.

49. However, membership of the WTO system requires unequivocal commitment to, and enforcement of, the multilateral rules; no country can be exempt therefrom. The WTO Agreement itself imposes a general obligation on each of its Members to ensure "the conformity of its laws, regulations and administrative procedures with the obligations as provided in the annexed Agreements". Many countries, in- 
cluding the developing countries in Asia and Africa and elsewhere, have already brought their domestic legislation into line with the aforesaid general obligation, or are in the process of doing so before the expiry of the relevant transition periods.

50. Compliance with this general obligation is particularly emergent in the case of the Agreements on Services, Trade-Related Aspects of Intellectual Property Rights (TRIPs) and Trade-Related Investment Measures (TRIMs) as they call for not only restructuring of existing legislation, but also the building up of requisite infrastructure and operative mechanisms in the national domain. The Agreement on Services obligates the Members of the WTO to enact domestic regulations for the administration of services in a reasonable and objective manner (MFN, transparency). The Agreement on TRIPs obligates the Members of the WTO to establish procedures and remedies in their domestic laws to ensure effective enforcement of Intellectual Property Rights (IPRs) through civil and administrative procedures which include provisions on evidence of proof, injunction, damages and other remedies, including the right of the judicial authorities to order the disposal or destruction of infringing goods. The developing countries and countries in transition have been given a five-year transition period, and the LDCs 11 years, during which they have to bring their laws and practices into conformity with the Agreement. Further, developing countries which do not presently provide product patent protection have been given 10 years to introduce such protection, although in case of pharmaceutical, agricultural and chemical products, the patent need not be granted until the end of the 10 year period. The TRIMs Agreement has prohibited investment measures which cause trade restrictions and distorting effects and requires mandatory notification of such measures and their disposal within two years. Thus, the existing legislation would need to be brought into line with the stipulations contained in the aforesaid Agreements.

\section{Conclusion}

51. Notwithstanding the transitional arrangements provided in the various WTO Agreements some of the issues involved definitely need further substantive and specific elaboration from the developing countries' standpoint before undertaking the revision of the relevant national legislation. The Secretariat of the AALCC, which is a major forum of Afro-Asian co-operation in the area of law and economic relations, can certainly assist its Member States in enacting or revising legislation so as to meet their obligations under the WTO system, but before embarking on the exercise it would be useful to have a general discussion in the AALCC focusing on the problems and difficulties being faced by them in enacting the WTO obligations in the national domain.

\subsection{Legislative activities of the United Nations and other organizations}

24. The Committee had before it document AALCC/XXXV/MANILA/96/9 entitled $R e$ port on legislative activities of the United Nations and other organizations concerned with international trade law, prepared by the Secretariat, covering recent work by the UN Commission on International Trade Law (UNCITRAL) (Draft Convention on Independent Guarantees and Standby Letters of Credit, Draft Model Law on Legal Aspects of Electronic Data Interchange (EDI) and Related Means of Communication, Draft Notes on Organizing Arbitral Proceedings, Assignment in Receivables Financing, Cross-border Insolvency, and Build-Operate- Transfer (BOT) projects); of the United Nations Conference on Trade and Development (UNCTAD), and the United Nations 
Industrial Development Organization (UNIDO), and of the Institute for the Unification of Private Law (UNIDROIT).

25. The Committee heard statements from Dr. Mohamed Aboul-Encin, Director of the Regional Centre for International Commercial Arbitration at Cairo, on the activities of arbitration institutions in the African region (Report, pp. 45-54); and by Ms. P.G. Lim, Director of the Regional Centre for Arbitration, Kuala Lumpur, on the activities of arbitration institutions in the Asia-Pacific region (Report, pp. 40-5). The latter statement contains the following:

"An account of the Kuala Lumpur Centre's activities for 1995 appears in page XIII 4 of the AALCC's Progress Report on the Regional Centres (Document No. AALCC/ XXXV/Manila/96/14) and I shall not repeat them here, but I would like to comment on some of the current issues mentioned in the Progress Report - in particular that relating to the existing Centres of Cairo and Kuala Lumpur and the establishment of additional Regional Centres. In this respect the establishment of the Kuala Lumpur Centre may help to focus attention on some of the important issues involved in setting up a new Centre.

\section{HISTORY}

When the Regional Centres were set up in the late seventies, it was hard to predict whether they could fulfil the purposes for which they were established. At that time the practice of western style arbitration was relatively unknown in the former colonial territories of Asia and Africa and institutional arbitration, a rare bird. Institutional arbitration centres for international arbitrations did not exist in the region and the Centres were created to fill that gap. The Centres were established on an experimental basis, were non-profit, and were to function under the supervision of the AALCC during the initial period of three years. ${ }^{1}$ [fn 1: Article 3. Administrative Rules of the KL Centre].

\section{FUNCTIONS}

As mentioned in the AALCC'S Progress Report (the Progress Report), the Centres were entrusted with certain broadbased functions such as the promotion of the institution of arbitration in dispute settlement; wider use and application of UNCITRAL Arbitration Rules 1976; establishment and growth of national arbitration institutions and agencies and encouraging inter-institutional co-operation between them; rendering assistance in the enforcement of awards. In addition, the Centres would also function as arbitration institutions in providing facilities for arbitration under their Rules. ${ }^{2}$ [fn 2: Ibid.]

\section{RULES OF THE CENTRES}

The procedural Rules for arbitration adopted by the Centres are those of UNCITRAL which had in 1976 promulgated these Rules. They were adopted by the UN General Assembly and were recommended to member countries for use in ad hoc arbitration. It was hoped that adoption of these Rules by member countries would lead to the harmonisation of arbitration Rules world-wide. The Regional Centres were the first arbitral institutions to adopt the UNCITRAL Rules. They were, therefore, the launching pad for these Rules which themselves were experimental in nature. It was not possible at the early stages to predict with any certainty whether these Rules would take off. 
NEW ARBITRAL INSTITUTIONS IN ASIA AND THE PACIFIC, 1985-1995

In Asia, interest has grown in arbitration as a means of dispute settlement especially in the last decade or so, following the establishment of the Kuala Lumpur Regional Centre. Its establishment was in some ways timely as it drew attention to the existence in the region of an international arbitral institution which could offer facilities and assistance for arbitration at a time when interest was growing in this field.

This in turn led many countries in the Asian region to set up arbitral institutions of their own so that business disputes could be settled within their own boundaries. The decade following the Centre's establishment saw a burgeoning of arbitration centres in the Pacific Rim and the emergence of new players in the field of international commercial arbitration, as follows :

1. Hongkong International Arbitration Centre (HKIAC), 1985;

2. Australian Centre for International Commercial Arbitration (ACICA), 1985;

3. Australian Commercial Disputes Centre, Sydney (ACDC), 1986;

4. British Columbian International Commercial Arbitration Centre (BCICAC) 1986;

5. American Arbitration Association (AAA) Asia-Pacific Centre in San Francisco, 1986;

6. Centre for International Commercial Dispute Resolution (CICDR), Hawaii, 1990 ;

7. Singapore International Arbitration Centre (SIAC), 1991;

8. The Thai Arbitration Institute, 1994;

9. The Vietnam International Arbitration Centre (VIAC), 1995.

$\cdots$

As national governments remodel their arbitration laws to create a favourable environment for international arbitration in their countries, this will result in fewer cases coming to the Centre.

In earlier years, the superior bargaining position of parties wishing to invest or trade in the Asian-African region meant that they could dictate the venue and the arbitral institutions to which disputes and differences arising out of business transactions would be referred to for arbitration. Inevitably, standard form contracts preferred by the buyers would contain reference to arbitration outside the region. In the two decades that followed the establishment of the Centres, the bargaining position of developing countries has improved from one of passive acceptance of a predetermined venue to that of being able to negotiate for themselves their preferred venue for arbitration. As the network of commercial transactions between the developed and developing world has expanded from the restricted colonial markets to those which now encompass the globe, developing countries can now 'shop' in any country of the world that can provide them with the tools, the cash and the technology that they need.

...

\section{THE EXPERIENCE OF THE KUALA LUMPUR CENTRE}

With few exceptions, unless a Centre enjoys a monopoly over arbitrations, it would be unrealistic to expect that running an Arbitration Centre would be a profitable exercise, particularly if it is non-profit. Unlike the Cairo Centre, the Kuala Lumpur Centre does not enjoy such a monopoly. It operates in a competitive environment where arbitrations, both domestic and international, are also administered by professional bodies, such as Associations of architects, engineers, quantity surveyors, Chambers of Commerce, as well as commodity associations of rubber and palm oil. 
Moreover, as it is non-profit, the administrative charges of the Kuala Lumpur Centre are a fraction of the arbitrator's fees. These charges cover the costs of servicing the arbitration; advising parties on the application of procedural rules of UNCITRAL and - as provided in the Rules - deciding on challenges to the arbitrators when questions about their impartiality or independence are raised; appointing arbitrators in default of appointment; and deciding on the amount of arbitrator's fees according to its Schedule of Fees; and collecting deposits - to name some of its responsibilities. These charges do not contribute much to the finances of the Centre. Nevertheless, the emphasis is to offer efficiency and quality service to the user of arbitration.

Another limiting factor in the number of cases coming to the Centre is the existence of standard form contracts which refer arbitrations to the established arbitral institutions in the West. Until businessmen are able to effect a change of venue in their contracts, this is a factor to be taken into account in setting up a Centre.

From information received, some contracts concluded in Indonesia, Thailand and India contain the Centre's arbitration clause but so far only one original dispute has been referred to the Centre and this originated from India.

Interest in arbitral services was indicated by recent visits from the Ministers of Justice of Vietnam, Laos, Indonesia and Thailand, seeking information on the Centre's facilities for arbitration and on the expenses and problems involved in setting up an Arbitration Centre. Information was provided and assistance offered in administering arbitrations for them, if need be.

According to a number of surveys conducted by the Centre between the years 1988-1993, among construction, shipping, oil and commodity sectors in Malaysia alone, there are now more than 5,000 contracts which have incorporated the Centre's arbitration clause in their contracts, but not all of them have reached the stage of arbitration. It must be concluded that a large number may have been settled. The fact that there is an arbitration clause which obliges parties to arbitrate sometimes leads to settlement before the stage of arbitration is reached.

Thus despite the fact that in Malaysia alone there is a large number of international contracts which contain the Centre's arbitration clause, the number of arbitrations conducted at the Centre is small. In fact, with the exception of the ICC, arbitration ceases form a relatively small part of the caseload of most institutions. ${ }^{3}$ [ $\mathrm{fn} 3$ : ICSID (The World Bank International Centre for Settlement of Investment Disputes) cases from date of inception 1966 to 1995 is 32.]

It is my impression that Centres which operate in an open, competitive environment cannot expect to attract a large number of international arbitrations. The new national Centres may, therefore, have to depend on active Government intervention and support to increase their international arbitration caseload. Promotional efforts will have to be carried out to encourage the public and private sectors to refer disputes to these Centres.

However, a Centre's importance should not be judged by the number of arbitrations handled by it. What interests the user, is the efficacy with which cases are handled, how problems which arise during arbitrations, some of which are outlined earlier, are solved, and above all, what steps are taken by the Centre or institution concerned to prevent tactical manoeuvres to frustrate the arbitral process.

In its pioneering efforts, the Centre was indeed fortunate to obtain from the host Government - Malaysia - not only financial support but legal logistics aimed at attracting international arbitrations to the Centre. The steps taken were as follows:

(1) In 1980, Malaysia amended its Arbitration Act 1952 to exclude International Arbitrations held under the Rules of the Centre from the ambit of the Arbitration Act (S. 34 of the Arbitration Act 1952);

(2) In 1985, the Government of Malaysia, having ratified the 1958 New York Convention, passed implementing legislation to bring its provisions into effect; 
(3) In its Agreement with the AALCC, the Government of Malaysia guarantees the independent functioning of the Centre.

In addition, the Malaysian Courts have given judicial support to the arbitral process in two notable decisions when they upheld :

(1) The right of parties to be represented by persons of their own choice in arbitrations held in Malaysia. [fn 4: Zublin Muhibbah Joint Venture v. Government of Malaysia (1990) 3 MLJ 125.]

(2) The principle of non-intervention of the Courts in arbitrations held under S. 34 of the Arbitration Act. The Court refused to intervene in a pending arbitration held under the Rules of the Centre.

I should add that the Malaysian Ministry of International Trade has also applied its efforts to recommend and encourage parties in joint venture contracts to refer their trade disputes to arbitration under the Centre's Rules. There is no question of compulsion here, as parties are free to choose where they want to arbitrate within Malaysia.

As announced by the Secretary-General a new Agreement has just been concluded between the Government of Malaysia and the AALCC for the continued functioning of the Kuala Lumpur Centre under the auspices of the AALCC. 